\title{
Effect of soil saturation on denitrification in a grassland soil
}

\author{
Laura Maritza Cardenas ${ }^{1}$, Roland Bol ${ }^{2}$, Dominika Lewicka-Szczebak ${ }^{3}$, Andrew Stuart Gregory ${ }^{4}$, \\ Graham Peter Matthews ${ }^{5}$, William Richard Whalley ${ }^{4}$, Thomas Henry Misselbrook ${ }^{1}$, David Scholefield ${ }^{1}$, and \\ Reinhard Well ${ }^{3}$ \\ ${ }^{1}$ Rothamsted Research, North Wyke, Okehampton, Devon EX20 2SB, UK \\ ${ }^{2}$ Institute of Bio- and Geosciences, IBG-3/Agrosphere, Forschungszentrum Jülich GmbH, 52428 Jülich, Germany \\ ${ }^{3}$ Thünen Institute of Climate-Smart Agriculture, Federal Research Institute for Rural Areas, Forestry and Fisheries, \\ Bundesallee, 50, 38116 Braunschweig, Germany \\ ${ }^{4}$ Rothamsted Research, Harpenden, Hertfordshire AL5 2JQ, UK \\ ${ }^{5}$ University of Plymouth, Drake Circus, Plymouth, Devon PL4 8AA, UK
}

Correspondence to: Laura Maritza Cardenas (laura.cardenas@ rothamsted.ac.uk)

Received: 22 December 2016 - Discussion started: 30 January 2017

Revised: 6 July 2017 - Accepted: 7 July 2017 - Published: 23 October 2017

\begin{abstract}
Nitrous oxide $\left(\mathrm{N}_{2} \mathrm{O}\right)$ is of major importance as a greenhouse gas and precursor of ozone $\left(\mathrm{O}_{3}\right)$ destruction in the stratosphere mostly produced in soils. The soil-emitted $\mathrm{N}_{2} \mathrm{O}$ is generally predominantly derived from denitrification and, to a smaller extent, nitrification, both processes controlled by environmental factors and their interactions, and are influenced by agricultural management. Soil water content expressed as water-filled pore space (WFPS) is a major controlling factor of emissions and its interaction with compaction, has not been studied at the micropore scale. A laboratory incubation was carried out at different saturation levels for a grassland soil and emissions of $\mathrm{N}_{2} \mathrm{O}$ and $\mathrm{N}_{2}$ were measured as well as the isotopocules of $\mathrm{N}_{2} \mathrm{O}$. We found that flux variability was larger in the less saturated soils probably due to nutrient distribution heterogeneity created from soil cracks and consequently nutrient hot spots. The results agreed with denitrification as the main source of fluxes at the highest saturations, but nitrification could have occurred at the lower saturation, even though moisture was still high (71\% WFSP). The isotopocules data indicated isotopic similarities in the wettest treatments vs. the two drier ones. The results agreed with previous findings where it is clear there are two $\mathrm{N}$ pools with different dynamics: added $\mathrm{N}$ producing intense denitrification vs. soil $\mathrm{N}$ resulting in less isotopic fractionation.
\end{abstract}

\section{Introduction}

Nitrous oxide $\left(\mathrm{N}_{2} \mathrm{O}\right)$ is of major importance as a greenhouse gas and precursor of ozone $\left(\mathrm{O}_{3}\right)$ destruction in the stratosphere (Crutzen, 1970). Agriculture is a major source of greenhouse gases (GHGs), such as carbon dioxide $\left(\mathrm{CO}_{2}\right)$, methane $\left(\mathrm{CH}_{4}\right)$ and also $\mathrm{N}_{2} \mathrm{O}$ (IPCC, 2006). The application of organic and inorganic fertiliser $\mathrm{N}$ to agricultural soils enhances the production of $\mathrm{N}_{2} \mathrm{O}$ (Baggs et al., 2000). This soil-emitted $\mathrm{N}_{2} \mathrm{O}$ is predominantly derived from denitrification and to a smaller extent, nitrification in soils (Davidson and Verchot, 2000). Denitrification is a microbial process in which reduction of nitrate $\left(\mathrm{NO}_{3}^{-}\right)$occurs to produce $\mathrm{N}_{2} \mathrm{O}$, and $\mathrm{N}_{2}$ is the final product of this process, benign for the environment, but represents a loss of $\mathrm{N}$ in agricultural systems. Nitrification is an oxidative process in which ammonium $\left(\mathrm{NH}_{4}^{+}\right)$is converted to $\mathrm{NO}_{3}^{-}$(Davidson and Verchot, 2000). Both processes are controlled by environmental factors and their interactions, and are influenced by agricultural management (Firestone and Davidson, 1989). It is well recognised that soil water content expressed as water-filled pore space (WFPS) is a major controlling factor, and as Davidson (1991) illustrated, nitrification is a source of $\mathrm{N}_{2} \mathrm{O}$ until WFPS values reach about $70 \%$, after which denitrification dominates. In fact, Firestone and Davidson (1989) gave oxygen supply a ranking of 1 in importance as a controlling factor in fertilised soils, above $\mathrm{C}$ and $\mathrm{N}$. At WFPS between 45 and $75 \%$ a mixture of nitrification and denitrification act as $\mathrm{N}_{2} \mathrm{O}$ sources. 
Davidson also suggested that at WFPS values above $90 \%$ only $\mathrm{N}_{2}$ is produced. Several studies have later proposed models to relate WFPS with emissions (Schmidt et al., 2000; Dobbie and Smith, 2001; Parton et al., 2001; del Prado et al., 2006; Castellano et al., 2010) but the "optimum" WFPS for $\mathrm{N}_{2} \mathrm{O}$ emissions varies from soil to soil (Davidson, 1991). Soil structure could be influencing this effect and it has been identified to strongly interact with soil moisture (Ball et al., 1999; van Groenigen et al., 2005) through changes in WFPS. Particularly soil compaction due to livestock treading and the use of heavy machinery affect soil structure and emissions as reported by studies relating bulk density to fluxes (Klefoth et al., 2014) and degrees of tillage to emissions (Ludwig et al., 2011).

Compaction is known to affect the size of the larger pores (macropores) thereby reducing the soil air volume and therefore increasing the WFPS (for the same moisture content) (van der Weerden et al., 2012). However, little is known about the effect of compaction on the smaller soil pores (micropores), and this could provide valuable information for understanding the simultaneous behaviour of the dynamics of water in the various pore sizes in soil. Such an understanding would lead to the development of better $\mathrm{N}_{2} \mathrm{O}$ mitigation strategies via dealing with soil compaction issues.

The role of water in soils is closely linked to microbial activity but also relates to the degree of aeration and gas diffusivity in soils (Morley and Baggs, 2010). Water facilitates nutrient supply to microbes and restricts gas diffusion, thereby increasing the residence time of gases in soil, and the chance of further $\mathrm{N}_{2} \mathrm{O}$ reduction before it can be released to the atmosphere. This is further aided by the restriction of the diffusion of atmospheric $\mathrm{O}_{2}$ (Dobbie and Smith, 2001), increasing the potential for denitrification. In consequence, counteracting effects (high microbial activity vs. low diffusion) occur simultaneously, making it difficult to predict net processes and corresponding outputs (Davidson, 1991). Detailed understanding of the sources of $\mathrm{N}_{2} \mathrm{O}$ and the influence of physical factors, i.e. soil structure and its interaction with moisture, is a powerful basis for developing effective mitigation strategies.

Isotopocules of $\mathrm{N}_{2} \mathrm{O}$ represent the isotopic substitution of the $\mathrm{O}$ and/or the two $\mathrm{N}$ atoms within the $\mathrm{N}_{2} \mathrm{O}$ molecule. The isotopomers of $\mathrm{N}_{2} \mathrm{O}$, are those differing in the peripheral $(\beta)$ and central $\mathrm{N}$ positions $(\alpha)$ of the linear molecule (Toyoda and Yoshida, 1999) with the intramolecular ${ }^{15} \mathrm{~N}$ site preference (SP; the difference between $\delta^{15} \mathrm{~N}^{\alpha}$ and $\delta^{15} \mathrm{~N}^{\beta}$ ) used to identify production processes at the level of microbial species or enzymes involved (Toyoda et al., 2005; Ostrom and Ostrom, 2011). Moreover, $\delta^{18} \mathrm{O}, \delta^{15} \mathrm{~N}$ and SP of emitted $\mathrm{N}_{2} \mathrm{O}$ depend on the denitrification product ratio $\left(\mathrm{N}_{2} \mathrm{O} /\left(\mathrm{N}_{2}+\mathrm{N}_{2} \mathrm{O}\right)\right)$ and hence provide insight into the dynamics of $\mathrm{N}_{2} \mathrm{O}$ reduction (Well and Flessa, 2009; LewickaSzczebak et al., 2014, 2015). Koster et al. (2013), for example, recently reported $\delta^{15} \mathrm{~N}^{\text {bulk }}$ values of $\mathrm{N}_{2} \mathrm{O}$ between -36.8 and $-31.9 \%$ under the conditions of their exper- iment, which are indicative of denitrification according to Perez et al. (2006) and Well and Flessa (2009), who proposed the range -54 to $-10 \%$ relative to the substrate. Baggs (2008) summarised that values between -90 and $-40 \%$ are indicative of nitrification. Determination of these values is normally carried out in pure culture studies or in conditions favouring either production or reduction of $\mathrm{N}_{2} \mathrm{O}$ (Well and Flessa, 2009). The SP is, however, considered a better predictor of the $\mathrm{N}_{2} \mathrm{O}$ source due to its independence from the substrate signature (Ostrom and Ostrom, 2011).

Simultaneous occurrence, production and reduction of $\mathrm{N}_{2} \mathrm{O}$ as in natural conditions present a challenge for isotopic factors determination due to uncertainty on $\mathrm{N}_{2} \mathrm{O}$ reduction and the co-existence of different microbial communities producing $\mathrm{N}_{2} \mathrm{O}$ (Lewicka-Szczebak et al., 2014). Recently, using data from the experiment reported here, where soil was incubated under aerobic atmosphere and the complete denitrification process occurs, Lewicka-Szczebak et al. (2015) determined fractionation factors associated with $\mathrm{N}_{2} \mathrm{O}$ production and reduction using a modelling approach. The analysis comprised measurements of the $\mathrm{N}_{2} \mathrm{O}$ and $\mathrm{N}_{2}$ fluxes combined with isotopocule data. Net isotope effects ( $\eta$ values) are variable to a certain extent as they result from a combination of several processes causing isotopic fractionation (Well et al., 2012). The results generally confirmed the range of values of $\eta$ (net isotope effects) and $\eta^{18} \mathrm{O} / \eta^{15} \mathrm{~N}$ ratios reported by previous studies for $\mathrm{N}_{2} \mathrm{O}$ reduction for that part of the soil volume were denitrification was enhanced by the $\mathrm{N}+\mathrm{C}$ amendment. This did not apply for the other part of the soil volume not reached by the $\mathrm{N}+\mathrm{C}$ amendment, showing that the validity of published net isotope effects for soil conditions with low denitrification activity still needs to be evaluated.

Lewicka-Szczebak et al. (2015) observed a clear relationship between ${ }^{15} \mathrm{~N}$ and ${ }^{18} \mathrm{O}$ isotope effects during $\mathrm{N}_{2} \mathrm{O}$ production and denitrification rates. For $\mathrm{N}_{2} \mathrm{O}$ reduction, differential isotope effects were observed for two distinct soil pools characterised by different product ratios $\mathrm{N}_{2} \mathrm{O} /\left(\mathrm{N}_{2}+\mathrm{N}_{2} \mathrm{O}\right.$ ). For moderate product ratios (from 0.1 to 1.0) the range of isotope effects given by previous studies was confirmed and refined, whereas for very low product ratios (below 0.1) the net isotope effects were much smaller. In this paper, we present the results from the gas emissions measurements from soils collected from a long-term permanent grassland soil to assess the impact of different levels of soil saturation on $\mathrm{N}_{2} \mathrm{O}$ and $\mathrm{N}_{2}$ and $\mathrm{CO}_{2}$ emissions after compaction. $\mathrm{CO}_{2}$ emissions were measured in addition as an estimate of aerobic respiration and thus of $\mathrm{O}_{2}$ consumption, which indicates denitrification is promoted. The measurements included the soil isotopomer $\left({ }^{15} \mathrm{~N}_{\alpha},{ }^{15} \mathrm{~N}_{\beta}\right.$ and site preference) analysis of emitted $\mathrm{N}_{2} \mathrm{O}$, which in combination with the bulk ${ }^{15} \mathrm{~N}$ and ${ }^{18} \mathrm{O}$ was used to distinguish between $\mathrm{N}_{2} \mathrm{O}$ from bacterial denitrification and other processes (e.g. nitrification and fungal denitrification) (Lewicka-Szczebak et al., 2017). 
We conducted measurements at defined saturation of pores size fractions as a prerequisite to model denitrification as a function of water status (Butterbach Bahl et al., 2013; Müller and Clough, 2014). We have under controlled conditions created a single compaction stress of $200 \mathrm{kPa}$ (typical of soils compacted after grazing) in incremental layers using a uniaxial pneumatic piston to simulate a grazing pressure. We hypothesised that at high water saturation, spatial heterogeneity of $\mathrm{N}$ emissions decreases due to more homogeneous distribution of the soil nutrients and/or anaerobic microsites. We also hypothesised that even at high soil moisture a mixture of nitrification and denitrification can occur. We base this on the creation of pockets of aerobicity as well of anaerobicity at high soil moisture, mainly driven by soil respiration after application of $\mathrm{N}$ and $\mathrm{C}$ (using up $\mathrm{O}_{2}$ ) and further recovery after nutrients are used becoming limiting (increasing aeration). We also aimed to assess how these effects (spatial heterogeneity and source processes) occur in a relatively narrow range of moisture (70-100\%). As far as we know there no other studies going to this level of detail. They mostly rely on the knowledge of the effect of moisture on soil processes, whilst in our study we combined direct measurements of both $\mathrm{N}_{2} \mathrm{O}$ and $\mathrm{N}_{2}$ with isotopomers of $\mathrm{N}_{2} \mathrm{O}$ to verify the source processes. In addition, the packing of the cores in our study was of great precision, increasing our potential to achieve reproducibility in the replicates where a mixture of aerobic/anaerobic pores might have occurred. We aimed to understand changes in the ratio $\mathrm{N}_{2} \mathrm{O} /\left(\mathrm{N}_{2} \mathrm{O}+\mathrm{N}_{2}\right)$ at the different moisture levels studied in a controlled manner on soil micro- and macropores. The $\mathrm{N}_{2}$ emissions were based on direct measurements from the incubated soils, avoiding methodologies that rely on inhibitors such as acetylene with limitations in diffusion in soil and causing oxidation of NO (Nadeem et al., 2013). Moreover, we used isotopocule values of $\mathrm{N}_{2} \mathrm{O}$ to evaluate whether the contribution of bacterial denitrification to the total $\mathrm{N}_{2} \mathrm{O}$ flux was affected by moisture status.

\section{Materials and methods}

\subsection{Soil used in the study}

An agricultural soil, under grassland management since at least 1838 (Barré et al., 2010), was collected from a location adjacent to a long-term ley-arable experiment at Rothamsted Research in Hertfordshire (Highfield; see soil properties in Table 1 and further details in Rothamsted Research, 2006; Gregory et al., 2010). The mixed sward is dominated by Lolium and Trifolium species and is cut two-three times a year. The soil was sampled as described in Gregory et al. (2010). Briefly, it was sampled from the upper $150 \mathrm{~mm}$ of the profile, air-dried in the laboratory, crumbled and sieved $(<4 \mathrm{~mm})$, mixed to make a bulk sample, and equilibrated at

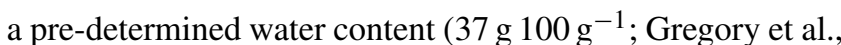
2010) in airtight containers at $4{ }^{\circ} \mathrm{C}$ for at least $48 \mathrm{~h}$.

\subsection{Preparation of soil blocks}

The equilibrated soil was then packed into 12 stainless-steel blocks (145 mm diameter; h: $100 \mathrm{~mm}$ ), each of which contained three cylindrical holes (i.d: $50 \mathrm{~mm}$; h: $100 \mathrm{~mm}$ each). The cores were packed to a single compaction stress of $200 \mathrm{kPa}$ in incremental layers using a uniaxial pneumatic piston. The three hole blocks were used to facilitate the compression of the cores. The $200 \mathrm{kPa}$ stress was analogous to a severe compaction event by a tractor (Gregory et al., 2010) or livestock (Scholefield et al., 1985). The total area of the upper surface of soil in each block was therefore $58.9 \mathrm{~cm}^{2}$ $\left(3 \times 19.6 \mathrm{~cm}^{2}\right)$ and the target volume of soil was set to be $544.28 \mathrm{~cm}^{3}\left(3 \times 181.43 \mathrm{~cm}^{3}\right)$ with the objective of leaving a headspace of approximately $45 \mathrm{~cm}^{3}\left(3 \times 15 \mathrm{~cm}^{3}\right)$ for the subsequent experiment. The precise height of the soil (and hence the volume) was measured using the displacement measurement system of a DN10 Test Frame (DavenportNene, Wigston, Leicester, UK) with a precision of $0.001 \mathrm{~mm}$.

\subsection{Equilibration of soil cores at different saturations}

The soil was equilibrated to four different initial saturation conditions or treatments ( $\mathrm{t} 0$ ) which were based on the likely distribution of water between macropores and micropores. The first treatment was where both the macro- and micropores (and hence the total soil) were fully saturated; the second treatment was where the macropores were half-saturated and the micropores remained fully saturated; the third treatment was where the macropores were fully unsaturated and the micropores again remained fully saturated; and the fourth treatment was where the macropores were fully unsaturated and the micropores were half-saturated. These four treatments are hereafter referred to as SAT/sat, HALFSAT/sat, UNSAT/sat and UNSAT/halfsat, respectively, where upper-case refers to the saturation condition of the macropores and lower-case refers to the saturation condition of the micropores. In order to set these initial saturation conditions, we referred to the gravimetric soil water release characteristic for the soil, as given in Gregory et al. (2010) (see Supplement). To achieve target water contents during the incubation, the amount of liquid added with the $\mathrm{C} / \mathrm{N}$ amendment $(15 \mathrm{~mL}$ ) was considered in the total volume of water added. For the SAT/sat and HALFSAT/sat conditions, two sets of three replicate blocks were placed on two fine-grade sand tension tables connected to a water reservoir. For the UNSAT/sat condition a set of three replicate blocks was placed on a tension plate connected to a water reservoir, and the final set of three replicate blocks was placed in pressure plate chambers connected to high-pressure air. All blocks were saturated on their respective apparatus for $24 \mathrm{~h}$, and were then equilibrated for 7 days at the adjusted target matric potentials which were achieved 
Table 1. Highfield soil properties.

\begin{tabular}{|c|c|c|}
\hline Property & Units & Highfield \\
\hline Location & & Rothamsted Research Herts. \\
\hline \multirow[t]{3}{*}{ Grid reference } & GB National Grid & TL129130 \\
\hline & Longitude & $00^{\circ} 21^{\prime} 48^{\prime \prime} \mathrm{W}$ \\
\hline & Latitude & $51^{\circ} 48^{\prime} 18^{\prime \prime} \mathrm{N}$ \\
\hline \multirow[t]{3}{*}{ Soil type } & SSEW $^{\mathrm{a}}$ group $^{\mathrm{c}}$ & Palaeo-argillic brown earth \\
\hline & SSEW $^{\mathrm{a}}$ series $^{\mathrm{d}}$ & Batcombe \\
\hline & $\mathrm{FAO}^{\mathrm{bc}}$ & Chromic Luvisol \\
\hline Land use & & Grass; unfertilised; cut \\
\hline $\mathrm{pH}$ & & 5.63 \\
\hline Sand $(2000-63 \mu \mathrm{m})$ & $\mathrm{g} \mathrm{g}^{-1}$ dry soil & 0.179 \\
\hline Silt $(63-2 \mu \mathrm{m})$ & $\mathrm{g} \mathrm{g}^{-1}$ dry soil & 0.487 \\
\hline Clay $(<2 \mu \mathrm{m})$ & $\mathrm{g} \mathrm{g}^{-1}$ dry soil & 0.333 \\
\hline Texture & SSEW $^{\mathrm{a}}$ class $^{\mathrm{c}}$ & Silty clay loam \\
\hline Particle density & $\mathrm{g} \mathrm{cm}^{-3}$ & 2.436 \\
\hline Organic matter & $\mathrm{g} \mathrm{g}^{-1}$ dry soil & 0.089 \\
\hline Water content for packing & $\mathrm{g} \mathrm{g}^{-1}$ dry soil & 0.37 \\
\hline
\end{tabular}

by either lowering the water level in the reservoir (sand tables and tension plate) or by increasing the air pressure (pressure chambers). At the end of equilibration period, the blocks were removed carefully from the apparatus, wrapped in airtight film, and maintained at $4{ }^{\circ} \mathrm{C}$ until the subsequent incubation.

\subsection{Incubation}

The study was carried out under controlled laboratory conditions, using a specialised laboratory denitrification (DENIS) incubation system (Cardenas et al., 2003). Each block containing three cores was placed in an individual incubation vessel of the automated laboratory system in a randomised block design to avoid effect of vessel. The lids for the vessels containing three holes were lined with the cores in the block to ensure that the solution to be applied later would fall on top of each soil core. Stainless steel bulkheads fitted (size for $1 / 4$ in. tubing) on the lids had a three-layered Teflon coated silicone septum ( $4 \mathrm{~mm}$ thick $\times 7 \mathrm{~mm}$ diameter) for supplying the amendment solution by using a gas tight hypodermic syringe. The bulkheads were covered with a stainless-steel nut and only open when amendment was applied. The incubation experiment lasted 13 days from the time the cores started to be flushed until the end of the incubation. The incubation vessels with the soils were contained in a temperature controlled cabinet and the temperature set at $20^{\circ} \mathrm{C}$. The incubation vessels were flushed from the bottom at a rate of $30 \mathrm{~mL} \mathrm{~min}^{-1}$ with a $\mathrm{He} / \mathrm{O}_{2}$ mixture $\left(21 \% \mathrm{O}_{2}\right.$, natural atmospheric concentration) for $24 \mathrm{~h}$, or until the system and the soil atmosphere were emitting low background levels of both $\mathrm{N}_{2}$ and $\mathrm{N}_{2} \mathrm{O}\left(\mathrm{N}_{2}\right.$ can get down to levels of $280 \mathrm{ppm}$ much smaller than atmospheric values). Subsequently, the $\mathrm{He} / \mathrm{O}_{2}$ supply was reduced to $10 \mathrm{~mL} \mathrm{~min}^{-1}$ and directed across the soil surface and measurements of $\mathrm{N}_{2} \mathrm{O}$ and $\mathrm{N}_{2}$ carried out at approximately 2-hourly cycles to sample from all the 12 vessels. Emissions of $\mathrm{CO}_{2}$ were simultaneously measured.

\subsection{Application of amendment}

An amendment solution equivalent to $75 \mathrm{~kg} \mathrm{Nha}^{-1}$ and $400 \mathrm{~kg} \mathrm{Cha}^{-1}$ was applied as a $5 \mathrm{~mL}$ aliquot a solution containing $\mathrm{KNO}_{3}$ and glucose to each of the three cores in each vessel on day 0 of the incubation. Glucose is added to optimise conditions for denitrification to occur (Morley and Baggs, 2010). The aliquot was placed in a stainless-steel container (volume 1.2 L) which had three holes drilled with bulkheads fitted: two to connect stainless-steel tubing for flushing the vessel and the third one to place a septum on a bulkhead to withdraw solution. Flushing was carried out with He for half an hour before the solution was required for application to the soil cores and continued during the application process to avoid atmospheric $\mathrm{N}_{2}$ contamination (a total of $1.5 \mathrm{~h}$ ). The amendment solution was manually withdrawn from the container with a glass syringe fitted with a three-way valve onto the soil surface; care was taken to minimise contamination from atmospheric $\mathrm{N}_{2}$ entering the system. The syringe content was injected to the soil cores via the inlets on the lids consecutively in each lid (three cores) and all vessels, completing a total of 36 applications that lasted about $45 \mathrm{~min}$. Incubation continued for 12 days, and the evolution of $\mathrm{N}_{2} \mathrm{O}$, $\mathrm{N}_{2}$ and $\mathrm{CO}_{2}$ was measured continuously. At the end of each incubation experiment, the soils were removed from the incubation vessels for further analysis. The three cores in each incubation vessel were pooled in one sample and subsamples 
taken and analysed for mineral $\mathrm{N}$, total $\mathrm{N}$ and $\mathrm{C}$, and moisture status.

\subsection{Gas measurements}

Gas samples were directed to the relevant analysers via an automated injection valve fitted with two loops to direct the sample to two gas chromatographs. Emissions of $\mathrm{N}_{2} \mathrm{O}$ and $\mathrm{CO}_{2}$ were measured by gas chromatographs (GCs), fitted with an electron capture detector (ECD) and separation achieved by a stainless-steel packed column ( $2 \mathrm{~m}$ long, $4 \mathrm{~mm}$ bore) filled with "Porapak Q" (80-100 mesh) and using $\mathrm{N}_{2}$ as the carrier gas. The detection limit for $\mathrm{N}_{2} \mathrm{O}$ was equivalent to $2.3 \mathrm{~g} \mathrm{Nha}^{-1} \mathrm{~d}^{-1}$. The $\mathrm{N}_{2}$ was measured by GC with a He ionisation detector (HID) and separation was achieved by a PLOT column ( $30 \mathrm{~m}$ long $0.53 \mathrm{~mm}$ i.d.), with $\mathrm{He}$ as the carrier gas. The detection limit was $9.6 \mathrm{~g} \mathrm{~N}^{-1} \mathrm{~d}^{-1}$. The response of the two GCs was assessed by measuring a range of concentrations for $\mathrm{N}_{2} \mathrm{O}, \mathrm{CO}_{2}$ and $\mathrm{N}_{2}$. Parent standards

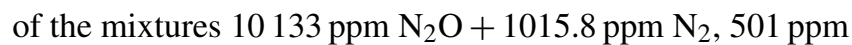
$\mathrm{N}_{2} \mathrm{O}+253 \mathrm{ppm} \mathrm{N}_{2}$, and $49.5 \mathrm{ppm} \mathrm{N}_{2} \mathrm{O}+100.6 \mathrm{ppm} \mathrm{N}_{2}$ were diluted by means of mass flow controllers with $\mathrm{He}$ to give a range of concentrations of up to $750 \mathrm{ppm}$ for $\mathrm{N}_{2} \mathrm{O}$ and 1015 ppm for $\mathrm{N}_{2}$. For $\mathrm{CO}_{2}$, a parent standard of $30100 \mathrm{ppm}$ was diluted down to $1136 \mathrm{ppm}$ (all standards were in $\mathrm{He}$ as the balance gas). Daily calibrations were carried out for $\mathrm{N}_{2} \mathrm{O}$ and $\mathrm{N}_{2}$ by using the low standard and doing repeated measurements. The temperature inside the refrigeration cabinet containing the incubation vessels was logged on an hourly basis and checked at the end of the incubation. The gas outflow rates were also measured and recorded daily, and subsequently used to calculate the flux.

\subsection{Measurement of $\mathrm{N}_{2} \mathrm{O}$ isotopic signatures}

Gas samples for isotopocule analysis were collected in $115 \mathrm{~mL}$ serum bottles sealed with grey butyl crimp-cap septa (part no. 611012, Altmann, Holzkirchen, Germany). The bottles were connected by a Teflon tube to the end of the chamber vents and were vented to the atmosphere through a needle in order to maintain flow through the experimental system. Dual isotope and isotopocule signatures of $\mathrm{N}_{2} \mathrm{O}$, i.e. $\delta^{18} \mathrm{O}$ of $\mathrm{N}_{2} \mathrm{O}\left(\delta^{18} \mathrm{O}-\mathrm{N}_{2} \mathrm{O}\right)$, average $\delta^{15} \mathrm{~N}\left(\delta^{15} \mathrm{~N}^{\text {bulk }}\right)$ and $\delta^{15} \mathrm{~N}$ from the central $\mathrm{N}$ position $\left(\delta^{15} \mathrm{~N}^{\alpha}\right)$ were analysed after cryofocussing by isotope ratio mass spectrometry as described previously (Well et al., 2008). ${ }^{15} \mathrm{~N}$ site preference (SP) was obtained as $\mathrm{SP}=2 \times\left(\delta^{15} \mathrm{~N}^{\alpha}-\delta^{15} \mathrm{~N}^{\text {bulk }}\right)$. Dual isotope and isotopocule ratios of a sample $\left(R_{\text {sample }}\right)$ were expressed as per mille deviation from ${ }^{15} \mathrm{~N} /{ }^{14} \mathrm{~N}$ and ${ }^{18} \mathrm{O} /{ }^{16} \mathrm{O}$ ratios of the reference standard materials $\left(R_{\mathrm{std}}\right)$, atmospheric $\mathrm{N}_{2}$ and standard mean ocean water (SMOW), respectively:

$\delta X=\left(R_{\text {sample }} / R_{\text {std }}-1\right) \times 1000$,

where $X={ }^{15} \mathrm{~N}^{\text {bulk }},{ }^{15} \mathrm{~N}^{\alpha},{ }^{15} \mathrm{~N}^{\beta}$, or ${ }^{18} \mathrm{O}$.

\subsection{Data analysis and additional measurements undertaken}

The areas under the curves for the $\mathrm{N}_{2} \mathrm{O}, \mathrm{CO}_{2}$ and $\mathrm{N}_{2}$ data were calculated by using GenStat 11 (VSN International Ltd, Hemel Hempstead, Herts, UK). The resulting areas for the different treatments were analysed by applying analysis of variance (ANOVA). The isotopic $\left({ }^{15} \mathrm{~N}^{\text {bulk }},{ }^{18} \mathrm{O}\right)$, and site preference (SP) differences between the four treatment for the different sampling dates were analysed by two-way ANOVA. We also used the Student's $t$ test to check for changes in soil water content over the course of the experiments.

Calculation of the relative contribution of the $\mathrm{N}_{2} \mathrm{O}$ derived from bacterial denitrification $\left(\% B_{\mathrm{DEN}}\right)$ was done according to Lewicka-Szczebak et al. (2015). The isotopic value of initially produced $\mathrm{N}_{2} \mathrm{O}$, i.e. prior to its partial reduction $\left(\delta_{0}\right)$, was determined using a Rayleigh model (Mariotti et al., 1982), were $\delta_{0}$ is calculated using the fractionation factor of $\mathrm{N}_{2} \mathrm{O}$ reduction $\left(\eta_{\left.\mathrm{N}_{2} \mathrm{O}-\mathrm{N}_{2}\right)}\right.$ for SP and the fraction of residual $\mathrm{N}_{2} \mathrm{O}\left(r_{\mathrm{N}_{2} \mathrm{O}}\right)$ which is equal to the $\mathrm{N}_{2} \mathrm{O} /\left(\mathrm{N}_{2}+\mathrm{N}_{2} \mathrm{O}\right)$ product ratio obtained from direct measurements of $\mathrm{N}_{2}$ and $\mathrm{N}_{2} \mathrm{O}$ flux. An endmember mixing model was then used to calculate the percentage of bacterial $\mathrm{N}_{2} \mathrm{O}$ in the total $\mathrm{N}_{2} \mathrm{O}$ flux $\left(\% B_{\mathrm{DEN}}\right)$ from calculated $\delta_{0}$ values and the SP and $\delta^{18} \mathrm{O}$ endmember values of bacterial denitrification and fungal denitrification/nitrification. The range in endmember and $\eta_{\mathrm{N}_{2} \mathrm{O}-\mathrm{N}_{2}}$ values assumed (adopted from Lewicka-Szczebak, 2017) to calculated maximum and minimum estimates of $\% B_{\mathrm{DEN}}$ is given in Table 4. We also fitted three functions through these data (SP vs. $\mathrm{N}_{2} \mathrm{O} /\left(\mathrm{N}_{2}+\mathrm{N}_{2} \mathrm{O}\right)$ ) including a second-degree polynomial and a linear and logarithmic function.

Because both, endmember values and $\eta_{\mathrm{N}_{2} \mathrm{O}-\mathrm{N}_{2}}$ values are not constant but subject to the given ranges, we calculated here several scenarios using combinations of maximum, minimum and average endmember and $\eta_{\mathrm{N}_{2} \mathrm{O}-\mathrm{N}_{2}}$ values (Table 4) to illustrate the possible range of $\% B_{\mathrm{DEN}}$ for each sample. For occasional cases where $\% B_{\mathrm{DEN}}>100 \%$ the values were set to $100 \%$.

At the same time as preparing the main soil blocks, a set of replicate samples was prepared in exactly the same manner, but in smaller cores (i.d: $50 \mathrm{~mm}$; h: $25 \mathrm{~mm}$ ). On these samples, we analysed soil mineral $\mathrm{N}$, total $\mathrm{N}$ and $\mathrm{C}$ and moisture at the start of the incubation. The same parameters were measured after incubation by doing destructive sampling from the cores. Mineral $\mathrm{N}\left(\mathrm{NO}_{3}^{-}, \mathrm{NO}_{2}^{-}\right.$and $\left.\mathrm{NH}_{4}^{+}\right)$was analysed after extraction with $\mathrm{KCl}$ by means of a segmented flow analyser using a colorimetric technique (Searle, 1984). Total C and $\mathrm{N}$ in the air-dried soil were determined using a thermal conductivity detector (TCD, Carlo Erba, model NA2000). Soil moisture was determined by gravimetric analysis after drying at $105^{\circ} \mathrm{C}$. 


\section{Results}

\subsection{Soil composition}

The results after moisture adjustment at the start of the experiment resulted in a range of WFPS of 100 to $71 \%$ for the four treatments (Table 2). The results from the end of the incubation also confirmed that there remained significant differences in soil moisture between the high-moisture treatments (SAT/sat and HALFSAT/sat) and the two lowermoisture treatments (Table 3; one-way ANOVA, $p<0.05$ ). Soils in the two wettest states lost statistically significant amounts of water $(10 \%(p=0.006)$ and $4.4 \%(p<0.001)$ for SAT/sat and HALFSAT/sat, respectively) over the course of the 13-day incubation experiment. This was inevitable as there was no way to hold a high (near-saturation) matric potential once the soil was inside the DENIS assembly, and water would have begun to drain by gravitational forces out of the largest macropores $(>30 \mu \mathrm{m})$. An additional factor was the continuous $\mathrm{He} / \mathrm{O}_{2}$ delivery over the soil surface which would have caused some drying. We accepted these as unavoidable features of the experimental set-up, but we assume that the main response of the gaseous emissions occurred under the initial conditions, prior to the loss of water over subsequent days. Soil in the two drier conditions had no significant change in their water content over the experimental period ( $p=0.153$ and 0.051 for UNSAT/sat and UNSAT/halfsat, respectively). The results of the initial soil composition for mineral $\mathrm{N}$ were $85.5 \mathrm{mg} \mathrm{NO}-\mathrm{N} \mathrm{kg}^{-1}$ dry soil and $136.2 \mathrm{mg} \mathrm{NH}_{4}^{+}-\mathrm{N} \mathrm{kg}^{-1}$ dry soil. The mineral $\mathrm{N}$ contents of the soils at the end of the incubation are reported in Table 3 , showing that $\mathrm{NO}_{3}^{-}$was very low in treatments $\mathrm{SAT} / \mathrm{sat}$ and HALFSAT/sat $\left(\sim 1 \mathrm{mg} \mathrm{N} \mathrm{kg}^{-1}\right.$ dry soil) compared to UNSAT/sat and UNSAT/halfsat (50-100 $\mathrm{mg} \mathrm{N} \mathrm{kg}^{-1}$ dry soil) at the end of the incubation. Therefore, there was a significant difference in soil $\mathrm{NO}_{3}^{-}$between the former highmoisture treatments and the latter drier (UNSAT) treatments, which were also significantly different between themselves $\left(p<0.001\right.$ for both). The $\mathrm{NH}_{4}^{+}$content was similar in treatments SAT/sat, HALFSAT/sat and UNSAT/sat ( $\sim 100 \mathrm{mg} \mathrm{N} \mathrm{kg}^{-1}$ dry soil), but slightly lower in treatment UNSAT/halfsat (71.3 $\mathrm{mg} \mathrm{N} \mathrm{kg}^{-1}$ dry soil); however, overall differences were not significant, probably due to the large variability on the driest treatment $(p>0.05)$.

\subsection{Gaseous emissions of $\mathrm{N}_{2} \mathrm{O}, \mathrm{CO}_{2}$ and $\mathrm{N}_{2}$}

All datasets of $\mathrm{N}_{2} \mathrm{O}$ and $\mathrm{N}_{2}$ emissions showed normal distribution (Fpr. $<0.001$ ). The treatments SAT/sat and HALFSAT/sat for all three gases $\left(\mathrm{N}_{2} \mathrm{O}, \mathrm{CO}_{2}\right.$ and $\left.\mathrm{N}_{2}\right)$ showed fluxes that were well replicated for all the vessels (see Fig. 1); in contrast, for UNSAT/sat and UNSAT/halfsat the emissions between the various replicated vessel in each treatment was not as consistent, leading to a larger within-treatment variability in the magnitude and shape of the GHG fluxes mea- sured. The cumulative fluxes also resulted in larger variability for the drier treatments (Table 3).

\subsubsection{Nitrous oxide and nitrogen gas}

The general trend was that the $\mathrm{N}_{2} \mathrm{O}$ concentrations in the headspace increased shortly after the application of the amendment (Fig. 1). The duration of the $\mathrm{N}_{2} \mathrm{O}$ peak for each replicate soil samples was about 3 days, except for UN$\mathrm{SAT} / \mathrm{halfsat}$, in which one of the replicate soils exhibits a peak which lasted for about 5 days. The $\mathrm{N}_{2} \mathrm{O}$ maximum in the SAT/sat and HALFSAT/sat treatments was of similar magnitude (means of 5.5 and $6.5 \mathrm{~kg} \mathrm{Nha}^{-1} \mathrm{~d}^{-1}$, respectively) but not those of UNSAT/sat and UNSAT/halfsat (means of 7.1 and $11.9 \mathrm{~kg} \mathrm{Nha}^{-1} \mathrm{~d}^{-1}$, respectively). The $\mathrm{N}_{2}$ concentrations always increased before the soil-emitted $\mathrm{N}_{2} \mathrm{O}$ reached the maximum. The lag between both $\mathrm{N}_{2} \mathrm{O}$ and $\mathrm{N}_{2}$ peak for all samples was only a few hours. Peaks of $\mathrm{N}_{2}$ generally lasted just over 4 days, except in UNSAT/halfsat, where one replicate lasted about 6 days (Fig. 1). Unlike in the $\mathrm{N}_{2} \mathrm{O}$ data, there was larger within treatment variability in the replicates for all four treatments. The standard deviations of each mean (Table 3) also indicate the large variability in treatments UNSAT/sat and UNSAT/halfsat for both $\mathrm{N}_{2} \mathrm{O}$ and $\mathrm{N}_{2}$.

The product ratios, i.e. $\mathrm{N}_{2} \mathrm{O} /\left(\mathrm{N}_{2} \mathrm{O}+\mathrm{N}_{2}\right)$, resulted in a peak just after amendment addition by ca. 0.73 (at 0.49 days), 0.65 (at 0.48 days), 0.99 (at 0.35 days) and 0.88 (at 0.42 days) for SAT/sat, HALFSAT/sat, UNSAT/sat and UNSAT/halfsat, respectively, and then decreases gradually until day 3 , where it becomes nearly zero for the two wettest treatments and stays stable for the driest treatments between 0.1 and 0.2 (see Table 5, where the daily means of these ratios are presented).

The cumulative areas of the $\mathrm{N}_{2} \mathrm{O}$ and $\mathrm{N}_{2}$ peaks analysed by one-way ANOVA resulted in no significant differences between treatments for both $\mathrm{N}_{2} \mathrm{O}$ and $\mathrm{N}_{2}$ (Table 3). Due to the large variation in treatments UNSAT/sat and UNSAT/halfsat we carried out a pair wise analysis by using a weighted $t$ test (Cochran and Cox, 1957). This analysis resulted in treatment differences between SAT/sat and HALFSAT/sat, HALFSAT/sat and UNSAT/sat, and SAT/sat and UNSAT/sat, but only at the $10 \%$ significance level $\left(P<0.1\right.$ for both $\mathrm{N}_{2} \mathrm{O}$ and $\mathrm{N}_{2}$ ).

The results showed that total $\mathrm{N}$ emission $\left(\mathrm{N}_{2} \mathrm{O}+\mathrm{N}_{2}\right)$ (Table 3) decreased between the highest and lowest soil moistures, i.e. from 63.4 for SAT/sat (100\% WFPS) to $34.1 \mathrm{~kg} \mathrm{Nha}^{-1}$ (71\% WFPS) for UNSAT/halfsat. The maximum cumulative $\mathrm{N}_{2} \mathrm{O}$ occurred at around $80 \%$ WFPS (Fig. 2), whereas the total $\mathrm{N}_{2} \mathrm{O}+\mathrm{N}_{2}$ was largest at about $95 \%$ and for $\mathrm{N}_{2}$ it was our upper treatment at $100 \%$ WFPS.

\subsubsection{Carbon dioxide}

The background $\mathrm{CO}_{2}$ fluxes (before amendment application, i.e. day -1 to day 0 ) were high at around $30 \mathrm{~kg} \mathrm{Cha}^{-1} \mathrm{~d}^{-1}$ 

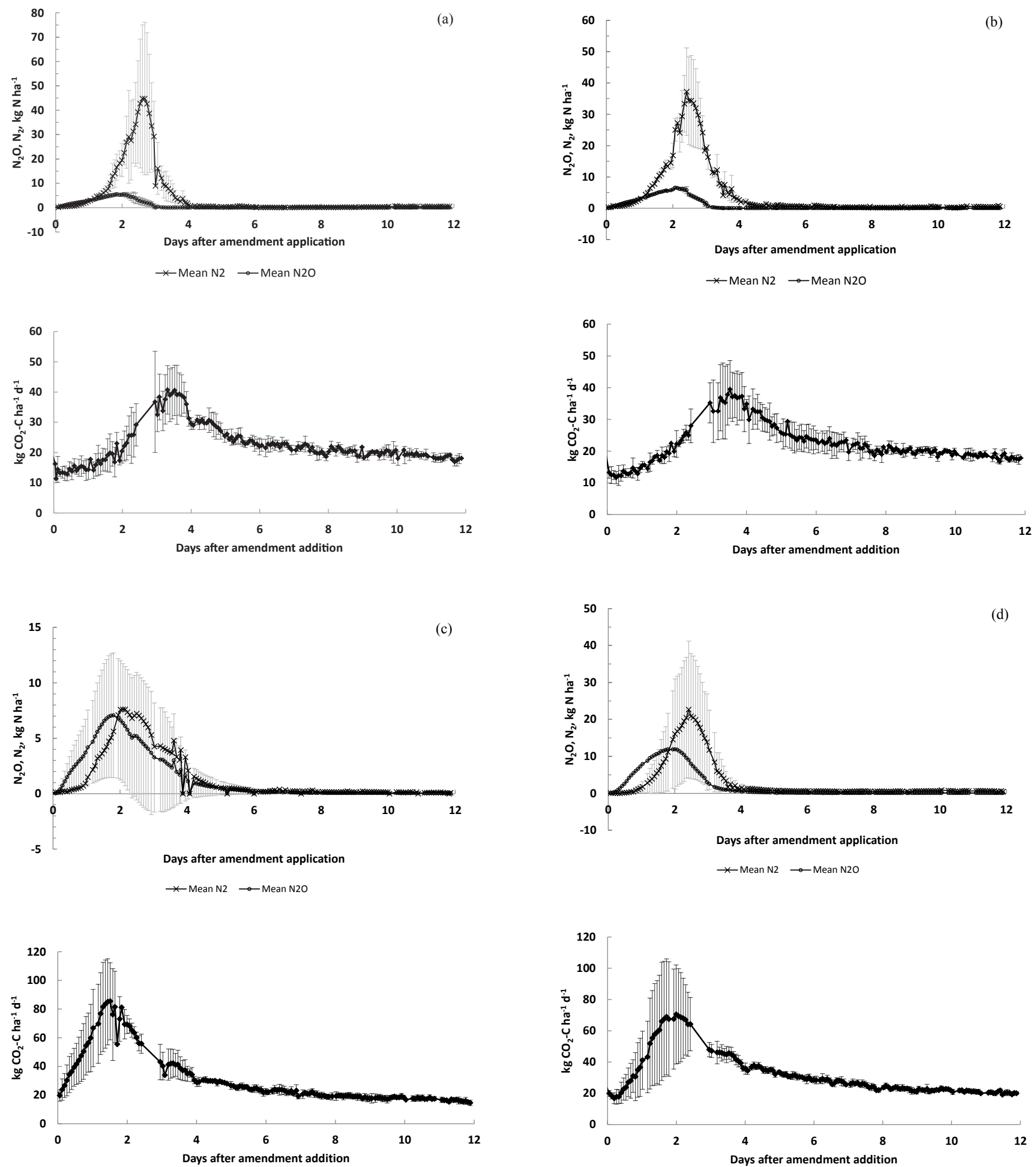

Figure 1. Mean of the three replicates for $\mathrm{N}_{2} \mathrm{O}, \mathrm{N}_{2}$ and $\mathrm{CO}_{2}$ emissions from (a) SAT/sat treatment, (b) HALFSAT/sat, (c) UNSAT/sat and (d) UNSAT/halfsat. Grey lines correspond to the standard error of the means (in $\mathbf{c}$ and $\mathbf{d}$ only errors for the $\mathrm{N}_{2}$ are shown to avoid overlapping of bars). 
Table 2. The four saturation conditions set for the Highfield soil.

\begin{tabular}{|c|c|c|c|c|}
\hline Saturation condition & $\mathrm{SAT} / \mathrm{sat}$ & HALFSAT/sat & UNSAT/sat & UNSAT/halfsat \\
\hline Macropores & Saturated & Half-saturated & Unsaturated & Unsaturated \\
\hline Micropores & Saturated & Saturated & Saturated & Half-saturated \\
\hline \multicolumn{5}{|l|}{ As prepared: } \\
\hline Matric potential, $\mathrm{kPa}$ & 4.1 & 12.3 & 27.3 & 136.9 \\
\hline Water content, g $100 \mathrm{~g}^{-1}$ & 47.7 & 42.5 & 37.2 & 29.4 \\
\hline Water content, $\mathrm{cm}^{-3} 100 \mathrm{~cm}^{-3}$ & 61.1 & 54.4 & 47.7 & 37.3 \\
\hline Water-filled pore space, $\%$ & 98 & 91 & 82 & 68 \\
\hline Threshold pore size saturated, $\mu \mathrm{m}$ & 73 & 24 & 11 & 2 \\
\hline \multicolumn{5}{|l|}{ Final, following amendment: } \\
\hline Matric potential, $\mathrm{kPa}$ & 0 & 8.6 & 20.0 & 78.1 \\
\hline Water content, g $100 \mathrm{~g}^{-1}$ & 49.8 & 44.6 & 39.3 & 31.5 \\
\hline Water content, $\mathrm{cm}^{-3} 100 \mathrm{~cm}^{-3}$ & 63.8 & 57.1 & 50.4 & 40.0 \\
\hline Water-filled pore space, $\%$ & 100 & 94 & 85 & 71 \\
\hline Threshold pore size saturated, $\mu \mathrm{m}$ & all & 35 & 15 & 4 \\
\hline
\end{tabular}

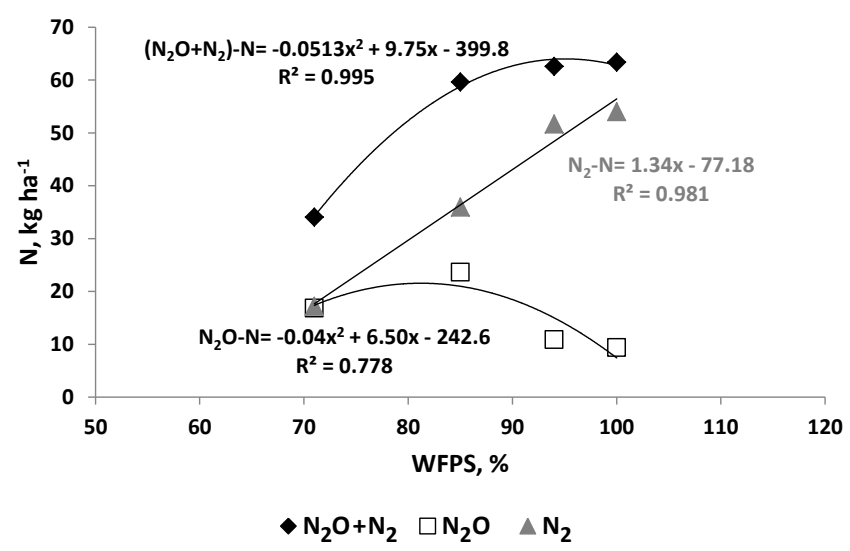

Figure 2. Total $\mathrm{N}$ emissions $\left(\mathrm{N}_{2} \mathrm{O}+\mathrm{N}_{2}\right)-\mathrm{N}, \mathrm{N}_{2} \mathrm{O}$ and $\mathrm{N}_{2}$ vs. WFPS. Fitted functions through each dataset are also shown.

and variable (not shown). The $\mathrm{CO}_{2}$ concentrations in the headspace increased within a few hours after amendment application. The maximum $\mathrm{CO}_{2}$ flux was reached earlier in the drier treatments (about 1-2 days; $\sim 70 \mathrm{~kg} \mathrm{Cha}^{-1} \mathrm{~d}^{-1}$ ) compared to the wettest ( 3 days; $\sim 40 \mathrm{~kg} \mathrm{Cha}^{-1} \mathrm{~d}^{-1}$ ) and former peaks were also sharper (Fig. 1). The cumulative $\mathrm{CO}_{2}$ fluxes were significantly larger in the two drier unsaturated treatments (ca. 400-420 $\mathrm{kg} \mathrm{Cha}^{-1}$ ) when compared to the wetter more saturated treatment (ca. $280-290 \mathrm{~kg} \mathrm{Cha}^{-1}, P<0.05$ ) (Table 3).

\subsubsection{Isotopocules of $\mathrm{N}_{2} \mathrm{O}$}

The $\delta^{15} \mathrm{~N}^{\text {bulk }}$ of the soil-emitted $\mathrm{N}_{2} \mathrm{O}$ in our study differed significantly among the four treatments and between the seven sampling dates ( $p<0.001$ for both); there was also a significant treatment $\times$ sampling date interaction $(p<$ $0.001)$. The maximum $\delta^{15} \mathrm{~N}^{\text {bulk }}$ generally occurred on day 3 , except for SAT/sat on day 4 (Table 6).
The maximum $\delta^{18} \mathrm{O}-\mathrm{N}_{2} \mathrm{O}$ values were also found on day 3 , except for SAT/sat, which peaked at day 2 (Table 6). Overall, the $\delta^{18} \mathrm{O}-\mathrm{N}_{2} \mathrm{O}$ values varied significantly between treatment and sampling dates $(p<0.001$ for both), but there was no significant treatment $\times$ time interaction $(p>0.05)$.

The site preference (SP) for the SAT/sat treatment had an initial maximum value on day $2(6.3 \%)$, which decreased thereafter in the period from day 3 to 5 to mean SP values of the emitted $\mathrm{N}_{2} \mathrm{O}$ of $2.0 \%$ on day 5 , subsequently rising to $8.4 \%$ on day 12 of the experiment (Table 6). The HALF$\mathrm{SAT} / \mathrm{sat}$ treatment had the highest initial SP values on day 2 and 3 (both $6.4 \%$ ), decreasing again to a value of $2.0 \%$, but now on day 4 followed by subsequent higher SP values of up to $9.2 \%$ on day 7 (Table 6). The two driest treatments (UNSAT/sat and UNSAT/halfsat) both had an initial maximum on day 3 (11.9 and 5.9\%o, respectively), and in UNSAT/sat the SP value then decreased to day 7 (3.9\%o). However, in the UNSAT/halfsat treatment, after a marginal decrease on day $4(5.4 \%$ ), it then increased throughout the experiment, reaching $11.8 \%$ on day 12 (Table 6). The lowest SP values were generally on day 1 in all treatments. Overall, for all parameters, there was more similarity between the more saturated treatments SAT/sat and HALFSAT/sat, and between the two more dry and aerobic treatments UNSAT/sat and UNSAT/halfsat.

The $\mathrm{N}_{2} \mathrm{O} /\left(\mathrm{N}_{2} \mathrm{O}+\mathrm{N}_{2}\right)$ ratios vs. SP for all treatments in the first 2 days (when $\mathrm{N}_{2} \mathrm{O}$ was increasing and the $\mathrm{N}_{2} \mathrm{O} /\left(\mathrm{N}_{2} \mathrm{O}+\mathrm{N}_{2}\right)$ ratio was decreasing) shows a significant negative response of the SP when the ratio increased (Fig. 3). This behaviour suggests that when the emitted gaseous $\mathrm{N}$ is dominated by $\mathrm{N}_{2} \mathrm{O}$ (ratio close to 1 ) the $\mathrm{SP}$ values will be slightly negative with an intercept of $-2 \%$ (Fig. 3), i.e. within the SP range of bacterial denitrification. With decreasing $\mathrm{N}_{2} \mathrm{O} /\left(\mathrm{N}_{2} \mathrm{O}+\mathrm{N}_{2}\right)$ ratio the SP values of soil-emitted $\mathrm{N}_{2} \mathrm{O}$ were increasing to values up to $8 \%$. This is in juxtaposition with the situation when the $\mathrm{N}$ emissions are dominated 


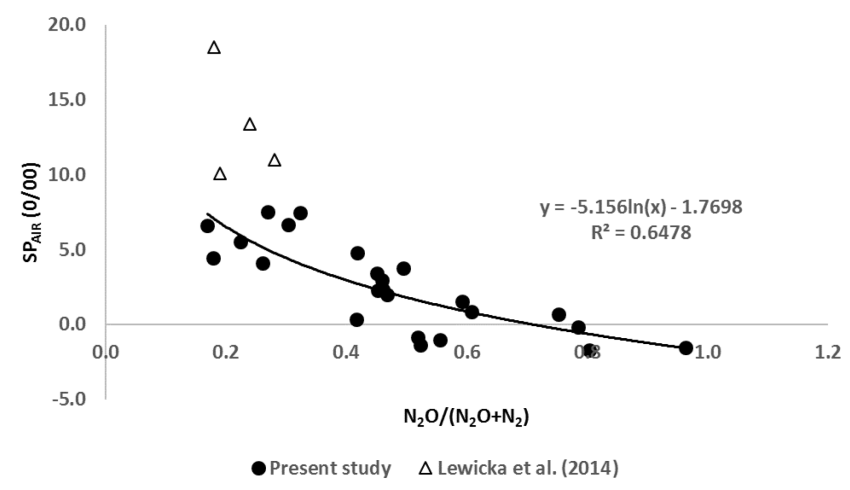

Figure 3. Ratio $\mathrm{N}_{2} \mathrm{O} /\left(\mathrm{N}_{2} \mathrm{O}+\mathrm{N}_{2}\right)$ vs. site preference (SP) for all for treatments in the first 2 days. A logarithmic function was fitted through the data; the corresponding equation and correlation coefficient are given. Also shown data from Lewicka et al. (2014).

by $\mathrm{N}_{2}$, or $\mathrm{N}_{2} \mathrm{O}$ is low, where the SP values of soil-emitted $\mathrm{N}_{2} \mathrm{O}$ were much higher (Fig. 3), pointing to an overall product ratio related to an "isotopic shift" of 10 to $12.5 \%$ o. The fitted logarithmic function in Fig. 3 is in almost perfect agreement with Lewicka-Szczebak et al. (2014).

It has been reported that the combination of the isotopic signatures of $\mathrm{N}_{2} \mathrm{O}$ potentially identifies the contribution of processes other than bacterial denitrification (Köster et al., 2015; Wu et al., 2016; Deppe et al., 2017). The question arises of to what extent the relationships between the $\delta^{18} \mathrm{O}$ and $\delta^{15} \mathrm{~N}^{\text {bulk }}$ and between $\delta^{18} \mathrm{O}$ and SP within the individual treatments denitrification dynamics are related. We checked this to evaluate the robustness of isotope effects during $\mathrm{N}_{2} \mathrm{O}$ reduction as a prerequisite to calculate the percentage of bacterial denitrification in $\mathrm{N}_{2} \mathrm{O}$ production. In our data, maximum $\delta^{18} \mathrm{O}$ and SP values were generally observed at or near the peak of $\mathrm{N}_{2}$ emissions on days 2-3, independent of the moisture treatment (Table 6 and Fig. 3). $\delta^{15} \mathrm{~N}^{\text {bulk }}$ values of all treatments were mostly negative when $\mathrm{N}_{2} \mathrm{O}$ fluxes started to increase (day 1, Fig. 1, Table 6), except for UNSAT/halfsat, in which the lowest value was before amendment application, reaching their highest values between days 3 and 4 for when $\mathrm{N}_{2} \mathrm{O}$ fluxes were back to the low initial values, and then decreased during the remaining period. $\delta^{18} \mathrm{O}$ values increased about 10-20\% after day 1 , reaching maximum values on days 2 or 3 in all treatments, while SP increased in parallel, at least by $3 \%$ (SAT/sat) and up to $12 \%$ (UNSAT/sat). While $\delta^{18} \mathrm{O}$ exhibited a steady decreasing trend after day 3 , SP behaved oppositely to $\delta^{15} \mathrm{~N}^{\text {bulk }}$ with decreasing values, while $\delta^{15} \mathrm{~N}^{\text {bulk }}$ was rising again after days 4 or 5 .

We further explored the data by looking at the relationships between the $\delta^{18} \mathrm{O}$ and $\delta^{15} \mathrm{~N}^{\text {bulk }}$ for all the treatments. The $\delta^{18} \mathrm{O}$ vs. $\delta^{15} \mathrm{~N}^{\text {bulk }}$ for all treatments is presented separating the data in three periods (see Fig. 4). There was a strong and significant relationship $(P<0.001$ and 0.05 , respectively) between $\delta^{18} \mathrm{O}$ vs. $\delta^{15} \mathrm{~N}^{\text {bulk }}$ for the high-moisture treatments $\left(R^{2}=0.973\right.$ and 0.923 for SAT/sat and HALF-
SAT/sat, respectively) at the beginning of the incubation ("12 ") when the $\mathrm{N}_{2} \mathrm{O}$ emissions are still increasing, in contrast to those of the lower soil moisture treatments that were lower and not significant $\left(R^{2}=0.294\right.$ and 0.622 , for UNSAT/sat and UNSAT/halfsat, respectively). The relationships between $\delta^{18} \mathrm{O}$ vs. $\delta^{15} \mathrm{~N}^{\text {bulk }}$ of emitted $\mathrm{N}_{2} \mathrm{O}$ for the " $3-12$ " period were significant for SAT/sat and HALFSAT/sat with $R^{2}$ values between 0.549 and 0.896 and $P$ values $<0.05$ and 0.001 , respectively (Fig. 4). Regressions were also significant for this period for the driest treatments $(P<0.001)$. Interestingly, with decreasing soil moisture content (Fig. 4a to d) the regression lines of " $1-2$ " and "3-12" day period got closer together in the graphs. Overall, the $\delta^{15} \mathrm{~N}^{\text {bulk }}$ isotopic distances between the two lines was larger for a given $\delta^{18} \mathrm{O}-\mathrm{N}_{2} \mathrm{O}$ value for SAT/sat and HALFSAT/sat (ca. 20\%o) when compared to the UNSAT/sat and UNSAT/halfsat treatments (ca. 13\%o) (Fig. 4). Therefore, it seems the $\delta^{15} \mathrm{~N}^{\text {bulk }} / \delta^{18} \mathrm{O}-\mathrm{N}_{2} \mathrm{O}$ signatures are more similar for the drier soils than the two wettest treatments. In addition, Fig. 4 exactly reflects the two-pool dynamics with increasing $\delta^{15} \mathrm{~N}$ and $\delta^{18} \mathrm{O}$ while the product ratio goes down (days 2,3 ), then only $\delta^{15} \mathrm{~N}$ continues increasing due to fractionation of the $\mathrm{NO}_{3}^{-}$during exhaustion of pool 1 in the wet soil (days 3, 4, 5). Finally, as pool 1 is depleted and more and more comes from pool 2, the product ratio increases somewhat, and $\delta^{15} \mathrm{~N}$ decreases somewhat since pool 2 is less fractionated and also $\delta^{18} \mathrm{O}$ decreases due to slightly increasing product ratio. Note that the turning points of $\delta^{18} \mathrm{O}$ and product ratio (Tables 3 and 4 ) for the wetter soils almost coincide.

Similarly to Fig. 4, $\delta^{18} \mathrm{O}$ vs. the SP (Fig. 5) was analysed for the different phases of the experiment. Generally, the slopes (Table 7) for days 1-2 for the three wettest treatments were similar $(\sim 0.2-0.3)$ following the range of known reduction slopes and also had high and significant $(P<$ $0.05)$ regression coefficients $\left(R^{2}=0.65,0.90\right.$ and 0.87 for $\mathrm{SAT} / \mathrm{sat}$, HALFSAT/Sat and UNSAT/sat, respectively). The slopes on days 3-5 were variable but slightly similar on days 7-12 (between 41 and 0.68) for the same three treatments. They were only significant for the two driest treatments $(P<0.05)$. On days $7-12 \mathrm{SAT} / \mathrm{sat}$ and UNSAT/sat gave significant correlations ( $P<0.001$ and 0.05 , respectively). Figure 5 also shows the "map" for the values of SP and $\delta^{18} \mathrm{O}$ from all treatments. Reduction lines (vectors) represent minimum and maximum routes of isotopocules values with increasing $\mathrm{N}_{2} \mathrm{O}$ reduction to $\mathrm{N}_{2}$ based on the reported range in the ratio between the isotope fractionation factors of $\mathrm{N}_{2} \mathrm{O}$ reduction for SP and $\delta^{18} \mathrm{O}$ (Lewicka-Szczebak et al. (2017). Most samples are located within the vectors (from LewickaSzczebak et al., 2017) area of $\mathrm{N}_{2} \mathrm{O}$ production by bacterial denitrification with partial $\mathrm{N}_{2} \mathrm{O}$ reduction to $\mathrm{N}_{2}$ (within uppermost and lowermost $\mathrm{N}_{2} \mathrm{O}$ reduction vectors representing the extreme values for the bacterial endmember and reduction slopes). Only a few values of the UNSAT/sat and UN$\mathrm{SAT} /$ halfsat treatments are located above that vector area and 

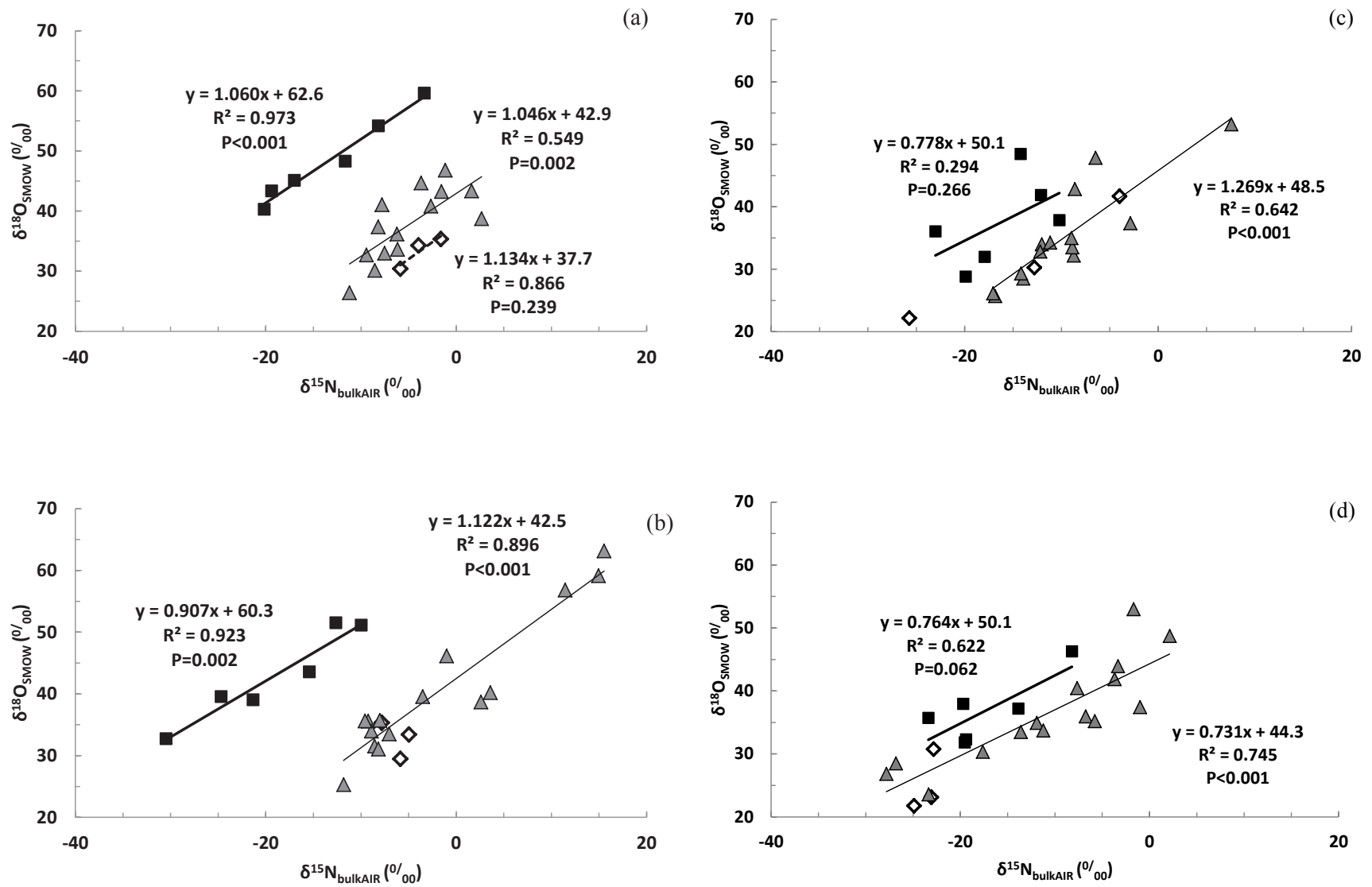

Figure 4. $\delta^{18} \mathrm{O}$ vs. $\delta^{15} \mathrm{~N}_{\text {bulk }}$ in all treatments for three periods: “-1", with $\delta^{18} \mathrm{O}$ vs. $\delta^{15} \mathrm{~N}^{\text {bulk }}$ values 1 day prior to the moisture adjustment (and $\mathrm{N}$ and $\mathrm{C}$ application); "1-2", with values in the first 2 days after the addition of water, $\mathrm{N}$ and $\mathrm{C}$, and $\mathrm{N}_{2} \mathrm{O}$ emissions were generally increasing in all treatments; and " $3-12$ ", the period in days after moisture adjustment and $\mathrm{N}$ and $\mathrm{C}$ addition when $\mathrm{N}_{2} \mathrm{O}$ emissions generally decreased back to baseline soil emissions (day -1 in diamond symbols, days 1-2 in square symbols and days 3-12 in triangle symbols) in the experiment. (a) SAT/sat treatment, (b) HALFSAT/sat, (c) UNSAT/sat and (d) UNSAT/halfsat. Equations of fitted functions and correlation coefficients are shown. Correlations are unadjusted; the $P$ value tests whether the slope is different from zero.

more close or within the vector area of mixing between bacterial denitrification and fungal denitrification/nitrification.

The estimated ranges of the proportion of emitted $\mathrm{N}_{2} \mathrm{O}$ resulting from bacterial denitrification $\left(\% B_{\mathrm{DEN}}\right)$ were on day 1 and 2 after the amendment comparable in all four moisture treatments (Table 6). However, during day 3 to 12 the $\% B_{\text {DEN }}$ ranged from 78 to $100 \%$ in SAT/sat and 79 to $100 \%$ HALFSAT/Sat, which was generally higher than that estimated at $54-86 \%$ for UNSAT/halfsat treatment. The $\% B_{\mathrm{DEN}}$ of UNSAT/halfsat in that period was intermediate between SAT/sat and UNSAT/sat with range of range 60-100\% (Table 6). The final values were similar to those on day -1 , except for the UNSAT/sat treatment.

\section{Discussion}

\section{1 $\mathrm{N}_{2} \mathrm{O}$ and $\mathrm{N}_{2}$ fluxes}

\subsubsection{Effect of soil moisture}

The observed decrease in total $\mathrm{N}$ emissions with decreasing initial soil moisture reflects the effect of soil moisture as reported in previous studies (Well et al., 2006). The differences when comparing the cumulative fluxes, however, were only marginally $(p<0.1)$ significant (Table 3$)$ mostly due to large variability within replicates in the drier treatments (see Fig. 1b). Davidson et al. (1991) provided a WFPS threshold for determination of source process, with a value of $60 \%$ WFPS as the borderline between nitrification and denitrification as source processes for $\mathrm{N}_{2} \mathrm{O}$ production. The WFPS in all treatments in our study was larger than $70 \%$, above this $60 \%$ threshold, and referred to as the "optimum water content" for $\mathrm{N}_{2} \mathrm{O}$ by Scheer et al. (2009), so we can be confident that denitrification was likely to have been the main 


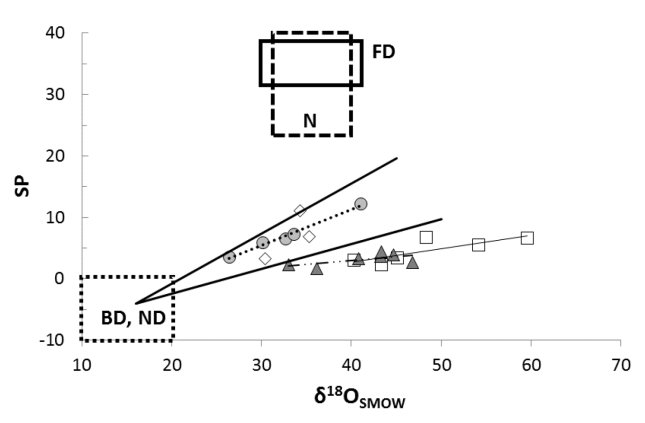

(a)

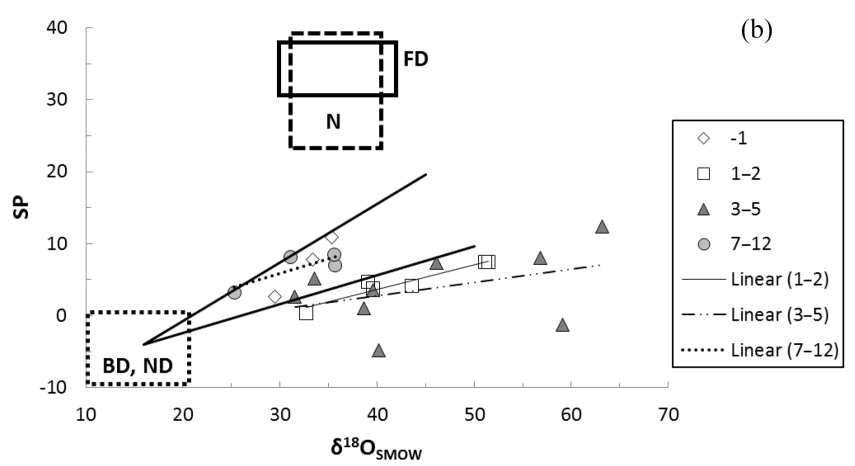

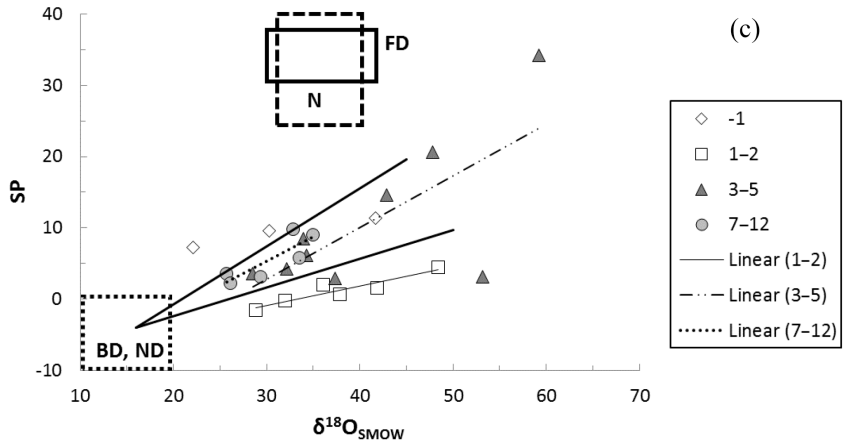

(d)

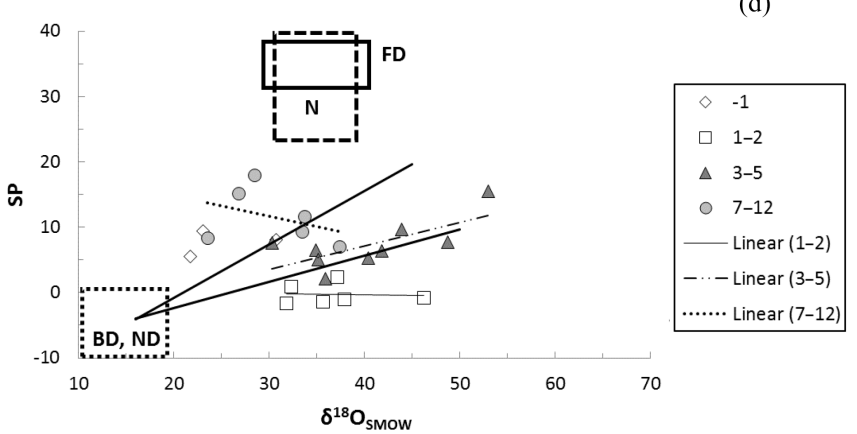

Figure 5. Site preference (\%o) vs. $\delta^{18} \mathrm{O}(\%$ ) in all treatments for three periods (day -1 , days $1-2$ and days $3-12)$ in the experiment: (a) SAT/sat treatment; (b) HALFSAT/sat; (c) UNSAT/sat; (d) UNSAT/halfsat. Equations of fitted functions and correlation coefficients are in Table 7 for 1-2, 3-5 and 7-12 (5-12 for c). Endmember areas for nitrification, N; bacterial denitrification, D; fungal denitrification, FD; and nitrifier denitrification, ND, as well as corresponding vectors or reduction lines (black solid lines) are from Lewicka-Szczebak et al. (2017) and represent minimum and maximum routes of isotopocule values with increasing $\mathrm{N}_{2} \mathrm{O}$ reduction to $\mathrm{N}_{2}$ based on the reported range in the ratio between the isotope fractionation factors of NO reduction for SP and $\delta^{18} \mathrm{O}$ (Lewicka-Szczebak et al., 2017).

source process in our experiment. In addition, Bateman et al. (2004) observed the largest $\mathrm{N}_{2} \mathrm{O}$ fluxes at $70 \%$ WFPS on a silty loam soil, lower than the $80 \%$ value for the largest fluxes from the clay soil in our study (Fig. 2), suggesting that this optimum value could change with soil type. Further, the maximum total measured $\mathrm{N}$ lost $\left(\mathrm{N}_{2} \mathrm{O}+\mathrm{N}_{2}\right)$ in our study occurred at about $95 \%$ WFPS (Fig. 2), but not many studies report $\mathrm{N}_{2}$ fluxes for comparison and we are still missing measurements of nitric oxide (NO) (Davidson et al., 2000) and ammonia $\left(\mathrm{NH}_{3}\right)$ to account for the total $\mathrm{N}$ losses. It is, however, possible that the $\mathrm{N}_{2} \mathrm{O}+\mathrm{N}_{2}$ fluxes in the SAT/sat treatment were underestimated due to low diffusivity in the water-filled pores (Well et al., 2001). Gases would have been trapped (particularly in the higher saturation treatments) due to low diffusion and thus possibly masked differences in $\mathrm{N}_{2}$ and $\mathrm{N}_{2} \mathrm{O}$ production since this fraction of gases was not detected (Harter et al., 2016). It is worth mentioning that there was some drying during the incubation. The flow of the gas is very slow $\left(10 \mathrm{~mL} \mathrm{~min}^{-1}\right)$, simulating a low wind speed, so normally this would dry the soil in field conditions too. It would represent a rainfall event where the initial moisture differs between treatments but some drying occurs due to the wind flow. We believe, however, that the effect of drying will be more relevant (and significant relative to the initial moisture) later in the incubation.

The smaller standard errors in both $\mathrm{N}_{2} \mathrm{O}$ and $\mathrm{N}_{2}$ data for the larger soil moisture levels (Table 3 and Fig. 1) could suggest that, at high moisture contents, nutrient distribution $(\mathrm{N}$ and $\mathrm{C}$ ) on the top of the core is more homogeneous, causing replicate cores to behave similarly. At the lower soil moisture for both $\mathrm{N}_{2} \mathrm{O}$ and $\mathrm{N}_{2}$, it is possible that some cracks appear on the soil surface, causing downwards nutrient movement, resulting in heterogeneity in nutrient distribution on the surface and increasing variability between replicates, reflected in the larger standard errors of the fluxes. Laudone et al. (2011) studied, using a biophysical model, the positioning of the hot-spot zones away from the critical percolation path (described as "where air first breaks through the structure as water is removed at increasing tensions") and found it slowed the increase and decline in emission of $\mathrm{CO}_{2}, \mathrm{~N}_{2} \mathrm{O}$ and $\mathrm{N}_{2}$. They found that hot-spot zones further away from the critical percolation path would reach the anaerobic conditions required for denitrification in shorter time, and the products of the denitrification reactions take longer to migrate from the hot-spot zones to the critical percolation path and to reach the surface of the system. The model and its parameters can be 


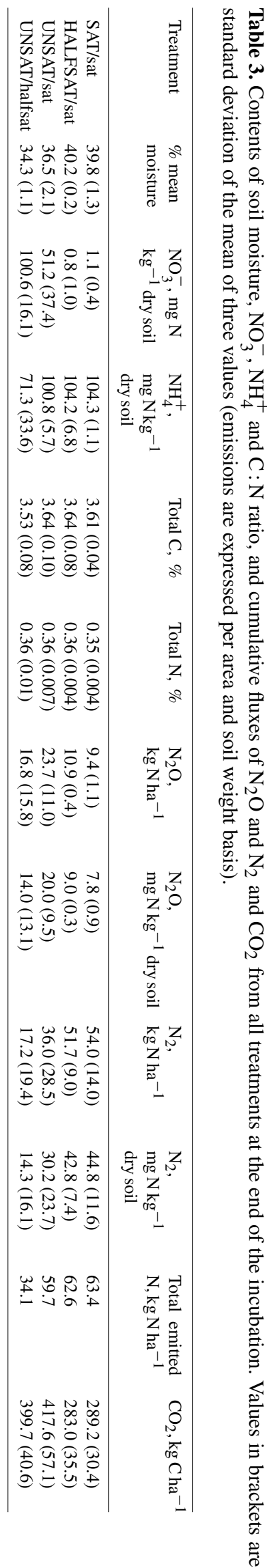

used for modelling the effect of soil compaction and saturation on the emission of $\mathrm{N}_{2} \mathrm{O}$. They suggest that, having determined biophysical parameters influencing $\mathrm{N}_{2} \mathrm{O}$ production, it remains to be determined whether soil structure, or simply saturation, is the determining factor when the biological parameters are constrained. Furthermore, Clough et al. (2013) indicate that microbial-scale models need to be included in larger models linking microbial processes and nutrient cycling in order to consider spatial and temporal variation. Kulkarni et al. (2008) refer to "hot spots" and "hot moments" of denitrification as scale-dependant and highlight the limitations for extrapolating fluxes to larger scales due to these inherent variabilities. In addition, in order to understand heterogeneity of added amendment, we assumed (for modelling purposes) multiple pools after $\mathrm{N}$ and glucose amendment. In Bergstermann et al. (2011), for example, we presumed they occupied $10 \%$ of the pore volume of the core (pool 1), because this resulted in a good fit for measured and modelled $\mathrm{N}_{2}$ and $\mathrm{N}_{2} \mathrm{O}$ fluxes as well as $\delta^{15} \mathrm{~N}^{\text {bulk }}$ values. In the current study, we could assume that in the wettest treatment this (proportional) volume was smaller, i.e. similar to the pore volume displaced by the added $5 \mathrm{~mL}$ of amendment, since pores were almost completely filled with water. Furthermore, we could assume that it would have been the largest in the driest treatment, where the amendment solution was also able to infiltrate air-filled pores in the partly saturated pore space and thereby increase the water content in the infiltrated volume. With regards to leaching, it was minimal $(<0.5 \mathrm{~mL}$ water in the core) and so significant leaching of amendment can thus be excluded. Other techniques such as X-ray and MRI could help determine the distribution of added nutrients in the soil matrix.

\subsubsection{Relationship with soil parameters to determine processes}

Our results, for the two highest water contents (SAT/sat and HALFSAT/sat), indicated that $\mathrm{N}_{2} \mathrm{O}$ only contributed $20 \%$ of the total $\mathrm{N}$ emissions, as compared to $40-50 \%$ at the lowest water contents (UNSAT/sat and UNSAT/halfsat, Table 3 ). This was due to reduction to $\mathrm{N}_{2}$ at the high moisture level, confirmed by the larger $\mathrm{N}_{2}$ fluxes, favoured by low gas diffusion, which increased the $\mathrm{N}_{2} \mathrm{O}$ residence time and the chance of further transformation (Klefoth et al., 2014). We should also consider the potential underestimation of the fluxes in the highest saturation treatment due to restricted diffusion in the water-filled pores (Well et al., 2001). A total of $99 \%$ of the soil $\mathrm{NO}_{3}^{-}$was consumed in the two high-water treatments, whereas in the drier UNSAT/sat and UNSAT/halfsat treatments there still was 35 and $70 \%$ of the initial amount of $\mathrm{NO}_{3}^{-}$left in the soil, at the end of the incubation, respectively (Table 3 ). The total amount of gas lost compared to the $\mathrm{NO}_{3}^{-}$consumed was almost 3 times greater for the wetter treatments, and less than twice for the two drier ones. This agrees with denitrification as the dominant process source for 
Table 4. Scenarios with different combinations of $\delta^{18} \mathrm{O}$ and site preference (SP) endmember values and $\eta_{\mathrm{N}_{2} \mathrm{O}-\mathrm{N}_{2}}$ values to calculate maximum and minimum estimates of $\% B_{\text {den }}$ (minimum, maximum and average values adopted from Lewicka-Szczabak et al., 2017).

\begin{tabular}{lrrrr}
\hline & SP0BD & SPOFDN & $\eta$ SP & $\eta^{18} \mathrm{O}$ \\
\hline Model (min endmember plus $\eta)$ & -11 & 30 & -2 & -12 \\
Model $(\max$ endmember plus $\eta)$ & 0 & 37 & -8 & -12 \\
Model $(\max$ endmember) & 0 & 37 & -5.4 & -12 \\
Model $(\min$ endmember) & -11 & 30 & -5.4 & -12 \\
Model $(\max \eta)$ & -5 & 33 & -8 & -12 \\
Model $(\min \eta)$ & -5 & 33 & -2 & -12 \\
\hline
\end{tabular}

Table 5. Ratios $\mathrm{N}_{2} \mathrm{O} /\left(\mathrm{N}_{2} \mathrm{O}+\mathrm{N}_{2}\right)$ for all treatments.

\begin{tabular}{lcr|lr|lr|rr}
\hline & \multicolumn{2}{c}{ SAT/sat } & \multicolumn{2}{c|}{ HALFSAT/sat } & \multicolumn{2}{c|}{ UNSAT/halfsat } & \multicolumn{2}{c}{ UNSAT/sat } \\
Days & mean & SE & mean & SE & mean & SE & mean & SE \\
\hline-1 & 0.276 & 0.043 & 0.222 & 0.009 & 0.849 & 0.043 & 0.408 & 0.076 \\
0 & 0.630 & 0.022 & 0.538 & 0.038 & 0.763 & 0.053 & 0.861 & 0.043 \\
1 & 0.371 & 0.025 & 0.360 & 0.019 & 0.622 & 0.018 & 0.644 & 0.031 \\
2 & 0.096 & 0.016 & 0.139 & 0.015 & 0.425 & 0.005 & 0.296 & 0.020 \\
3 & 0.004 & 0.002 & 0.015 & 0.006 & 0.439 & 0.052 & 0.256 & 0.025 \\
4 & 0.017 & 0.002 & 0.008 & 0.001 & 0.475 & 0.049 & 0.232 & 0.012 \\
5 & 0.019 & 0.003 & 0.012 & 0.001 & 0.503 & 0.037 & 0.174 & 0.010 \\
6 & 0.068 & 0.008 & 0.020 & 0.001 & 0.459 & 0.052 & 0.135 & 0.010 \\
7 & 0.085 & 0.008 & 0.047 & 0.003 & 0.333 & 0.057 & 0.127 & 0.003 \\
8 & 0.106 & 0.004 & 0.066 & 0.002 & 0.277 & 0.006 & 0.122 & 0.002 \\
9 & 0.089 & 0.003 & 0.053 & 0.005 & 0.265 & 0.006 & 0.122 & 0.005 \\
10 & 0.060 & 0.003 & 0.090 & 0.014 & 0.428 & 0.086 & 0.118 & 0.006 \\
11 & 0.063 & 0.002 & 0.053 & 0.002 & 0.414 & 0.051 & 0.125 & 0.005 \\
\hline
\end{tabular}

$\mathrm{N}_{2} \mathrm{O}$ with larger consumption of $\mathrm{NO}_{3}^{-}$at the higher moisture and larger $\mathrm{N}_{2}$ to $\mathrm{N}_{2} \mathrm{O}$ ratios $(5.7,4.7$ for SAT/sat and HALF$\mathrm{SAT} / \mathrm{sat}$, respectively), whereas at the lower moisture, ratios were lower (1.5 and 1.0 for UNSAT/sat and UNSAT/halfsat, respectively) (Davidson, 1991). This also indicates that with WFPS above the $60 \%$ threshold for $\mathrm{N}_{2} \mathrm{O}$ production from denitrification, there was an increasing proportion of anaerobic microsites with increase in saturation controlling $\mathrm{NO}_{3}^{-}$ consumption and $\mathrm{N}_{2} / \mathrm{N}_{2} \mathrm{O}$ ratios in an almost linear manner. With WFPS values between 71 and $100 \%$ and $\mathrm{N}_{2} / \mathrm{N}_{2} \mathrm{O}$ between 1.0 and 5.7, a regression can be estimated: $Y=0.1723$ $X-11.82\left(R^{2}=0.8585\right)$, where $Y$ is $\mathrm{N}_{2} / \mathrm{N}_{2} \mathrm{O}$ and $X$ is $\%$ WFPS. In summary, we propose that heterogeneous distribution of anaerobic microsites could have been the limiting factor for complete depletion of $\mathrm{NO}_{3}^{-}$and conversion to $\mathrm{N}_{2} \mathrm{O}$ in the two drier treatments. In addition, in the UNSAT/halfsat treatment there was a decrease in soil $\mathrm{NH}_{4}^{+}$at the end of the incubation (almost 50\%; Table 3), suggesting nitrification could have been occurring at this water content which also agrees with the increase in $\mathrm{NO}_{3}^{-}$, even though WFPS was relatively high $(>71 \%)$ (Table 3$)$. It is important to note that as we did not assess gross nitrification, the observed net nitrification based on lowering in $\mathrm{NH}_{4}^{+}$could underestimate gross nitrification since there might have been substantial $\mathrm{N}$ mineralisation during the incubation. However, under conditions favouring denitrification at high soil moisture the typical $\mathrm{N}_{2} \mathrm{O}$ produced from nitrification is much lower compared to that from denitrification (Lewicka-Szczebak et al., 2017) with the maximum reported values for the $\mathrm{N}_{2} \mathrm{O}$ yield of nitrification of 1-3\% (e.g. Deppe et al., 2017). If this is the case, nitrification fluxes could not have exceeded $1 \mathrm{~kg} \mathrm{~N}$ with $\mathrm{NH}_{4}^{+}$ loss of $<30 \mathrm{~kg} \times 3 \% \sim 1 \mathrm{~kg} \mathrm{~N}$. This would have represented for the driest treatment, if conditions were suitable only for one day, that nitrification-derived $\mathrm{N}_{2} \mathrm{O}$ would have been $6 \%$ of the total $\mathrm{N}_{2} \mathrm{O}$ produced. Loss of $\mathrm{NH}_{3}$ was not probable at such low $\mathrm{pH}$ (5.6). The corresponding rate of $\mathrm{NO}_{3}^{-}$production using the initial and final soil contents and assuming other processes were less important in magnitude would have been $<1 \mathrm{mg} \mathrm{NO}_{3}^{-}-\mathrm{N} \mathrm{kg} \mathrm{dry} \mathrm{soil}^{-1} \mathrm{~d}^{-1}$, which is a reasonable rate (Hatch et al., 2002). The other three treatments lost similar amounts of soil $\mathrm{NH}_{4}^{+}$during the incubation (23-26\%), which could have been due to some degree of nitrification at the start of the incubation before $\mathrm{O}_{2}$ was depleted in the soil microsites or due to $\mathrm{NH}_{4}^{+}$immobilisation (Table 3) (Geisseler et al., 2010).

A mass $\mathrm{N}$ balance, considering the initial and final soil $\mathrm{NO}_{3}^{-}, \mathrm{NH}_{4}^{+}$, added $\mathrm{NO}_{3}^{-}$and the emitted $\mathrm{N}$ (as $\mathrm{N}_{2} \mathrm{O}$ and $\mathrm{N}_{2}$ ), results in unaccounted-for $\mathrm{N}$ loss of 177.2, 177.6, 130.6 and 
Table 6. The temporal trends in $\delta^{15} \mathrm{~N}_{\text {bulk }}, \delta^{18} \mathrm{O}, \delta^{15} \mathrm{~N}_{\alpha}$, site preference (SP) and $\% B_{\mathrm{DEN}}$ for all experimental treatments (values in brackets are the standard deviation of the mean).

\begin{tabular}{|c|c|c|c|c|}
\hline \multirow[b]{2}{*}{ Day } & \multicolumn{4}{|c|}{$\delta^{15} \mathrm{~N}_{\text {bulkAIR }}(\% o)$} \\
\hline & SAT/sat & HALFSAT/sat & UNSAT/sat & UNSAT/halfsat \\
\hline-1 & $-3.8(2.1)$ & $-6.2(1.5)$ & $-14.2(10.9)$ & $-23.6(1.1)$ \\
\hline 1 & $-18.9(1.6)$ & $-25.5(4.6)$ & $-20.3(2.6)$ & $-20.8(2.3)$ \\
\hline 2 & $-7.7(4.2)$ & $-12.7(2.7)$ & $-12.2(2.0)$ & $-13.9(5.7)$ \\
\hline 3 & $-2.4(1.8)$ & $14.0(2.2)$ & $-1.1(7.6)$ & $-4.4(3.0)$ \\
\hline 4 & $-0.9(2.2)$ & $-0.3(3.6)$ & $-7.8(4.6)$ & $-9.3(3.7)$ \\
\hline 5 & $-6.9(0.9)$ & $-4.3(6.1)$ & $-11.3(3.7)$ & $-8.9(7.7)$ \\
\hline 7 & $-9.6(1.5)$ & $-10.0(1.6)$ & $-14.3(4.7)$ & $-13.4(13.5)$ \\
\hline \multirow[t]{3}{*}{12} & $-7.5(1.2)$ & $-8.6(0.9)$ & $-11.8(2.6)$ & $-21.3(6.9)$ \\
\hline & \multicolumn{4}{|c|}{$\delta^{18} \mathrm{O}_{\mathrm{SMOW}}(\% o)$} \\
\hline & SAT/sat & HALFSAT/sat & UNSAT/sat & UNSAT/halfsat \\
\hline-1 & $33.3(2.6)$ & $32.7(3.0)$ & $31.4(9.8)$ & $25.2(4.9)$ \\
\hline 1 & $42.9(2.4)$ & $37.1(3.8)$ & $32.3(3.6)$ & $33.3(2.1)$ \\
\hline 2 & $54.0(5.7)$ & $48.7(4.5)$ & $42.7(5.3)$ & $40.5(5.0)$ \\
\hline 3 & $45.7(1.5)$ & $59.7(3.2)$ & $53.4(5.7)$ & $41.2(1.0)$ \\
\hline 4 & $42.5(1.4)$ & $42.0(3.7)$ & $38.1(4.5)$ & $39.9(7.7)$ \\
\hline 5 & $36.0(2.9)$ & $34.6(3.7)$ & $30.4(2.6)$ & $36.5(6.9)$ \\
\hline 7 & $32.2(5.5)$ & $31.6(5.5)$ & $28.4(4.4)$ & $32.7(5.4)$ \\
\hline \multirow[t]{3}{*}{12} & $34.9(5.6)$ & $34.1(2.7)$ & $32.4(2.9)$ & $28.5(5.0)$ \\
\hline & \multicolumn{4}{|c|}{$\delta^{15} \mathrm{~N} \alpha_{\mathrm{AIR}}(\% \circ)$} \\
\hline & SAT/sat & HALFSAT/sat & UNSAT/sat & UNSAT/halfsat \\
\hline-1 & $-0.3(3.4)$ & $-2.6(1.8)$ & $-9.5(12.0)$ & $-19.7(2.1)$ \\
\hline 1 & $-17.4(1.8)$ & $-24.0(5.8)$ & $-20.2(2.0)$ & $-21.1(2.6)$ \\
\hline 2 & $-4.6(4.2)$ & $-9.5(3.6)$ & $-11.1(1.1)$ & $-13.8(5.9)$ \\
\hline 3 & $-0.8(1.3)$ & $17.2(4.0)$ & $7.6(4.7)$ & $-2.7(3.2)$ \\
\hline 4 & $1.0(2.5)$ & $0.7(2.2)$ & $-3.5(3.7)$ & $-2.8(7.7)$ \\
\hline 5 & $-5.9(0.7)$ & $-2.9(5.4)$ & $-9.4(3.9)$ & $-5.2(7.9)$ \\
\hline 7 & $-7.8(2.3)$ & $-5.3(4.2)$ & $-12.3(5.6)$ & $-7.7(11.5)$ \\
\hline \multirow[t]{3}{*}{12} & $-3.3(2.1)$ & $-4.6(0.6)$ & $-8.1(4.2)$ & $-15.3(5.5)$ \\
\hline & \multicolumn{4}{|c|}{$\mathrm{SP}_{\mathrm{AIR}}(\% o)$} \\
\hline & SAT/sat & HALFSAT/sat & UNSAT/sat & UNSAT/halfsat \\
\hline-1 & $7.0(3.9)$ & $7.1(4.2)$ & $9.4(2.1)$ & 7.7 (1.9) \\
\hline 1 & $2.9(0.6)$ & $3.0(2.3)$ & $0.1(1.8)$ & $-0.7(1.4)$ \\
\hline 2 & $6.3(0.64)$ & $6.4(1.9)$ & $2.2(2.0)$ & $0.2(1.9)$ \\
\hline 3 & $3.3(1.0)$ & $6.4(6.9)$ & $11.9(12.4)$ & $5.9(0.8)$ \\
\hline 4 & $3.7(0.6)$ & $2.0(6.2)$ & $8.7(5.9)$ & $5.4(3.0)$ \\
\hline 5 & $2.0(0.4)$ & $3.0(2.1)$ & $3.9(0.5)$ & $7.4(2.3)$ \\
\hline 7 & $5.0(2.1)$ & $9.2(5.2)$ & $3.9(1.8)$ & $11.2(4.1)$ \\
\hline \multirow[t]{3}{*}{12} & $8.4(3.3)$ & $7.9(0.8)$ & $7.3(3.7)$ & $11.8(5.3)$ \\
\hline & \multicolumn{4}{|c|}{ Estimated range of $\% B_{\mathrm{DEN}}$} \\
\hline & $\mathrm{SAT} / \mathrm{sat}$ & HALFSAT/sat & UNSAT/sat & UNSAT/halfsat \\
\hline-1 & $63-100$ & $60-100$ & $53-85$ & $56-84$ \\
\hline $1-2$ & $68-100$ & $67-100$ & $73-100$ & $77-100$ \\
\hline $3-12$ & $78-100$ & $79-100$ & $60-100$ & $54-86$ \\
\hline
\end{tabular}


Table 7. Equations of fitted functions and correlation coefficients corresponding to Fig. 5 for site preference (SP) ( $y$ axis) vs. $\delta^{18} \mathrm{O}(x$ axis) in all treatments for three periods. Correlations are unadjusted; the $P$ value tests whether the slope is different from zero.

\begin{tabular}{llll}
\hline Treatment & Days 1-2 & Days 3-5 & Days 7-12 \\
\hline SAT/sat & $y=0.2151 x-5.8386, R^{2}=$ & $y=0.1204 x-1.848, R^{2}=0.397$ & $y=0.5872 x-12.223, R^{2}=$ \\
& 0.6529 & $P=0.129$ & 0.985 \\
& $P=0.05$ & & $P<0.001$ \\
\hline HALFSAT/sat & $y=0.3447 x-10.129, R^{2}=$ & $y=0.18 x-4.5966, R^{2}=0.1728$ & $y=0.4063 x-6.2632, R^{2}=$ \\
& 0.9048 & $P=0.266$ & 0.6876 \\
& $P=0.004$ & & $P=0.171$ \\
\hline UNSAT/sat & $y=0.2709 x-8.9968, R^{2}=$ & $y=0.7248 x-18.874, R^{2}=$ & $y=0.6848 x-15.236, R^{2}=$ \\
& 0.8664 & 0.507 & 0.7156 \\
& $P=0.007$ & $P=0.031$ & $P=0.034$ \\
\hline UNSAT/halfsat & $y=-0.0146 x+0.2506, R^{2}=$ & $y=0.3589 x-7.2194, R^{2}=$ & $y=-0.318 x+21.261, R^{2}=$ \\
& 0.0024 & 0.4839 & 0.1491 \\
& $P=0.927$ & $P=0.037$ & $P=0.450$ \\
\hline
\end{tabular}

$110.8 \mathrm{mg} \mathrm{N} \mathrm{kg}^{-1}$ for SAT/sat, HALFSAT/sat, UNSAT/sat and UNSAT/halfsat, respectively, that could have been emitted as other $\mathrm{N}$ gases (such as $\mathrm{NO}$ ), and some immobilised in the microbial biomass. NO fluxes reported by Loick et al. (2016), for example, result in a ratio $\mathrm{N}_{2} \mathrm{O} / \mathrm{NO}$ of 0.4 . In summary, unaccounted-for $\mathrm{N}$ loss is 2 to 3 times the total measured gas loss (Table 3 ). In addition, in the SAT/sat treatment there was probably an underestimation of the produced $\mathrm{N}_{2}$ and $\mathrm{N}_{2} \mathrm{O}$ due to restricted diffusion at the high WFPS (e.g. Well et al., 2001).

\subsubsection{Implications for field distribution of fluxes}

Well et al. (2003) found that under saturated conditions there was good agreement between laboratory and field measurements of denitrification, and attributed deviations, under unsaturated conditions, to spatial variability of anaerobic microsites and redox potential. Dealing with spatial variability when measuring $\mathrm{N}_{2} \mathrm{O}$ fluxes in the field remains a challenge, but the uncertainty could be potentially reduced if water distribution is known. Our laboratory study suggests that soil $\mathrm{N}_{2} \mathrm{O}$ and $\mathrm{N}_{2}$ emission for higher moisture levels would be less variable than for drier soils and suggests that for the former a smaller number of spatially defined samples will be needed to get an accurate field estimate. This applied to a lesser extent to the $\mathrm{CO}_{2}$ fluxes.

\subsection{Isotopocule trends}

Trends of isotopocule values of emitted $\mathrm{N}_{2} \mathrm{O}$ coincided with those of $\mathrm{N}_{2}$ and $\mathrm{N}_{2} \mathrm{O}$ fluxes. The results from the isotopocule data (Table 6 and Fig. 3) also indicated that generally there were more isotopic similarities between the two wettest treatments when compared to the two contrasting drier soil moisture treatments.
Isotopocule values of emitted $\mathrm{N}_{2} \mathrm{O}$ reflect multiple processes where all signatures are affected by the admixture of several microbial processes, the extent of $\mathrm{N}_{2} \mathrm{O}$ reduction to $\mathrm{N}_{2}$ and the variability of the associated isotope effects (Lewicka-Szczebak et al., 2015). Moreover, for $\delta^{18} \mathrm{O}$ and $\delta^{15} \mathrm{~N}^{\text {bulk }}$ the precursor signatures are variable (Decock and Six, 2013), and for $\delta^{18} \mathrm{O}$ the $\mathrm{O}$ exchange with water can be also variable (Lewicka-Szczebak et al., 2017). Since the number of influencing factors clearly exceeds the number of isotopocule values, unequivocal results can only be obtained if certain processes can be excluded or be determined independently (Lewicka-Szczebak et al., 2015, 2017). The two latter conditions were fulfilled in this study, i.e. $\mathrm{N}_{2} \mathrm{O}$ fluxes were high and several orders of magnitude above possible nitrification fluxes, since the $\mathrm{N}_{2} \mathrm{O}-$ to $-\mathrm{NO}_{3}^{-}$ratio yield of nitrification products rarely exceeds $1 \%$ (Well et al., 2008). Moreover, $\mathrm{N}_{2}$ fluxes and thus $\mathrm{N}_{2} \mathrm{O}$ reduction rates were exactly quantified.

The estimated values of $\% B_{\mathrm{DEN}}$ indicate that, in the period immediately after amendment application, all moisture treatments were similar, reflecting that the microbial response to $\mathrm{N}$ and $\mathrm{C}$ added was the same and denitrification dominated. This was the same for the rest of the period for the wetter treatments. In the drier treatments, proportions decreased afterwards and were similar to values before amendment application, possibly due to recovery of more aerobic conditions that could have encouraged other processes to contribute. As $\mathrm{N}_{2}$ was still produced in the driest treatment (but in smaller amounts), this indicated ongoing denitrifying conditions and thus large contributions to the total $\mathrm{N}_{2} \mathrm{O}$ flux from nitrification were not probable, but some occurred as suggested by $\mathrm{NH}_{4}^{+}$consumption.

The trends observed reflect the dynamics resulting from the simultaneous application of $\mathrm{NO}_{3}^{-}$and labile $\mathrm{C}$ (glucose) on the soil surface as described in previous studies (Meijide 
et al., 2010; Bergstermann et al., 2011) where the same soil was used, resulting in two locally distinct $\mathrm{NO}_{3}^{-}$pools with differing denitrification dynamics. In the soil volume reached by the $\mathrm{NO}_{3}^{-}$/ glucose amendment, denitrification was initially intense with high $\mathrm{N}_{2}$ and $\mathrm{N}_{2} \mathrm{O}$ fluxes and rapid isotopic enrichment of the $\mathrm{NO}_{3}^{-}-\mathrm{N}$. When the $\mathrm{NO}_{3}^{-}$and/or glucose of this first pool was exhausted, $\mathrm{N}_{2}$ and $\mathrm{N}_{2} \mathrm{O}$ fluxes were much lower and dominated by the initial $\mathrm{NO}_{3}^{-}$pool that was not reached by the glucose $/ \mathrm{NO}_{3}^{-}$amendment and that is less fractionated due to its lower exhaustion by denitrification, causing decreasing trends in $\delta^{15} \mathrm{~N}^{\text {bulk }}$ of emitted $\mathrm{N}_{2} \mathrm{O}$.

This is also reflected in Fig. 4, where $\mathrm{N}_{2} \mathrm{O}$ fluxes from both pools exhibited correlations (and mostly significant) between $\delta^{15} \mathrm{~N}^{\text {bulk }}$ and $\delta^{18} \mathrm{O}$ due to varying $\mathrm{N}_{2} \mathrm{O}$ reduction, but $\delta^{15} \mathrm{~N}^{\text {bulk }}$ values in days 1 and 2 - i.e. the phase when pool 1 dominated - were distinct from the previous and later phase.

The fit of ${ }^{15} \mathrm{~N}^{\text {bulk }} /{ }^{18} \mathrm{O}$ data to two distinct and distant regression lines can be attributed to two facts: firstly, in the wet treatment (Fig. 4a, b) pool 1 was probably completely exhausted and there was little $\mathrm{NO}_{3}^{-}$formation from nitrification (indicated by final $\mathrm{NO}_{3}^{-}$values close to 0 , Table 3 ), whereas the drier treatment exhibited substantial $\mathrm{NO}_{3}^{-}$formation and high residual $\mathrm{NO}_{3}^{-}$. Hence, there was probably still some $\mathrm{N}_{2} \mathrm{O}$ from pool 1 after day 2 in the dry treatment but not in the wetter ones. Secondly, the product ratios after day 2 of the drier treatments were higher ( 0.13 to 0.44 ) compared to the wetter treatments (0.001 to 0.09$)$. Thus the isotope effect of $\mathrm{N}_{2} \mathrm{O}$ reduction was smaller in the drier treatments, leading to a smaller upshift of $\delta^{15} \mathrm{~N}^{\text {bulk }}$ and thus more negative values after day 2 , i.e. with values closer to days $1+2$.

This finding further confirms that $\delta^{15} \mathrm{~N} / \delta^{18} \mathrm{O}$ patterns are useful to identify the presence of several $\mathrm{N}$ pools, e.g. typically occurring after application of liquid organic fertilisers, which has been previously demonstrated using isotopocule patterns (Koster et al., 2015).

Interestingly, the highest $\delta^{15} \mathrm{~N}^{\text {bulk }}$ and $\delta^{18} \mathrm{O}$ values of the emitted $\mathrm{N}_{2} \mathrm{O}$ were found in the soils of the HALF$\mathrm{SAT} / \mathrm{sat}$ treatment, although it may have been expected that the highest isotope values from the $\mathrm{N}_{2} \mathrm{O}$ would be found in the wettest soil (SAT/sat) because $\mathrm{N}_{2} \mathrm{O}$ reduction to $\mathrm{N}_{2}$ is favoured under water-saturated conditions due to extended residence time of produced $\mathrm{N}_{2} \mathrm{O}$ (Well et al., 2012). However, $\mathrm{N}_{2} \mathrm{O} /\left(\mathrm{N}_{2}+\mathrm{N}_{2} \mathrm{O}\right)$ ratios of the SAT/sat and SAT/halfsat treatments were not different (Table 5). Bol et al. (2004) also found that some estuarine soils under flooded conditions (akin to our SAT/sat) showed some strong simultaneous depletions (rather than enrichments) of the emitted $\mathrm{N}_{2} \mathrm{O}$ $\delta^{15} \mathrm{~N}^{\text {bulk }}$ and $\delta^{18} \mathrm{O}$ values. These authors suggested that this observation may have resulted from a flux contribution of an "isotopically" unidentified $\mathrm{N}_{2} \mathrm{O}$ production pathway. Another explanation could be complete consumption of some of the produced $\mathrm{N}_{2} \mathrm{O}$ in isolated micro-niches in the SAT/sat treatment due to inhibited diffusivity in the fully saturated pore space. $\mathrm{N}_{2}$ formation in these isolated domains would not affect the isotopocule values of emitted $\mathrm{N}_{2} \mathrm{O}$ and this would thus result in lower apparent isotope effects of $\mathrm{N}_{2} \mathrm{O}$ reduction in water saturated environments as suggested by Well et al. (2012).

The SP values obtained were generally below $12 \%$, in agreement with reported ranges attributed to bacterial denitrification: -2.5 to $1.8 \%$ o (Sutka et al., 2006), 3.1 to $8.9 \%$ o (Well and Flessa, 2009) and -12.5 to $17.6 \%$ (Ostrom and Ostrom, 2011). The SP, believed to be a better predictor of the $\mathrm{N}_{2} \mathrm{O}$ source as it is independent of the substrate isotopic signature (Ostrom and Ostrom, 2011), has been suggested as it can be used to estimate $\mathrm{N}_{2} \mathrm{O}$ reduction to $\mathrm{N}_{2}$ in cases when bacterial denitrification can be assumed to dominate $\mathrm{N}_{2} \mathrm{O}$ fluxes (Koster et al., 2013; Lewicka-Szczebak et al., 2015). There was a strong correlation between the SP and $\mathrm{N}_{2} \mathrm{O} /\left(\mathrm{N}_{2} \mathrm{O}+\mathrm{N}_{2}\right)$ ratios on the first 2 days of the incubation for all treatments up until the $\mathrm{N}_{2} \mathrm{O}$ reached its maximum (Fig. 3), which reflects the accumulation of $\delta^{15} \mathrm{~N}$ at the alpha position during ongoing $\mathrm{N}_{2} \mathrm{O}$ reduction to $\mathrm{N}_{2}$. Later on in the experiment, beyond day 3 , this was not observed probably because in that period the product ratio remained almost unchanged and very low (Table 6). Similar observations have been reported by Meijide et al. (2010) and Bergstermann et al. (2011), as they also found a decrease in SP during the peak flux period in total $\mathrm{N}_{2}+\mathrm{N}_{2} \mathrm{O}$ emissions, but only when the soil had been kept wet prior to the start of the experiment (Bergstermann et al., 2011). These results confirm from two independent studies (Lewicka-Szczebak et al., 2014) that there is a relationship between the product ratios and isotopic signatures of the $\mathrm{N}_{2} \mathrm{O}$ emitted. The $\delta^{18} \mathrm{O}$ vs. SP regressions indicate more similarity between the three wettest treatments as well as high regression coefficients, suggesting this $\mathrm{SP} / \delta^{18} \mathrm{O}$ ratio could also be used to help identify patterns for emissions and their sources.

\subsection{Link to modelling approaches.}

Since isotopocule data could be compared to $\mathrm{N}_{2}$ and $\mathrm{N}_{2} \mathrm{O}$ fluxes, the variability of isotope effects of $\mathrm{N}_{2} \mathrm{O}$ production and reduction to $\mathrm{N}_{2}$ by denitrification could be determined from this dataset (Lewicka-Szczebak et al., 2015), and this included modelling the two pool dynamics discussed above. It was demonstrated that net isotope effects of $\mathrm{N}_{2} \mathrm{O}$ reduction $\left(\eta_{\mathrm{N}_{2} \mathrm{O}-\mathrm{N}_{2}}\right)$ determined for both $\mathrm{NO}_{3}^{-}$pools differed. Pool 1 representing amended soil and resulting in high fluxes but moderate product ratio, exhibited $\eta_{\mathrm{N}_{2} \mathrm{O}-\mathrm{N}_{2}}$ values and the characteristic $\eta^{18} \mathrm{O} / \eta^{15} \mathrm{~N}$ ratios similar to those previously reported, whereas for pool 2 (amendment-free soil), characterised by lower fluxes and very low product ratio, the net isotope effects were much smaller and the $\eta^{18} \mathrm{O} / \eta^{15} \mathrm{~N}$ ratios, previously accepted as typical for $\mathrm{N}_{2} \mathrm{O}$ reduction processes (i.e. higher than 2), were not valid. The question arises of whether the poor coincidence of pool 2 isotopologue fluxes with previous $\mathrm{N}_{2} \mathrm{O}$ reduction studies reflects the variability of isotope effects of $\mathrm{N}_{2} \mathrm{O}$ reduction or whether the contribution 
of other processes like fungal denitrification could explain this (Lewicka-Szczabak et al., 2017). The latter explanation is evaluated in Sect. 4.4.

Liu et al. (2016) noted that on the catchment-scale potential $\mathrm{N}_{2} \mathrm{O}$ emission rates were related to hydroxylamine and $\mathrm{NO}_{3}^{-}$, but not $\mathrm{NH}_{4}^{+}$content in soil. Zou et al. (2014) found high SP (15.0 to $20.1 \%$ ) values at WFPS of 73 to $89 \%$, suggesting that fungal denitrification and bacterial nitrification contributed to $\mathrm{N}_{2} \mathrm{O}$ production to a degree equivalent to that of bacterial denitrification.

To verify the contribution of fungal denitrification and/or hydroxylamine oxidation we can first look at the $\eta \mathrm{SP}_{\mathrm{N}_{2} \mathrm{O}-\mathrm{NO}_{3}}$ values calculated in the previous modelling study applied on the same dataset (Table 1, the final modelling step; Lewicka-Szczebak et al., 2015). For pool 1 there are no significant differences between the values of various treatments, $\mathrm{SP}_{0}$ ranges from $(-1.8 \pm 4.9)$ to $(+0.1 \pm 2.5)$. Pool 1 emission was mostly active in days $1-2$; hence, these values confirm the bacterial dominance in the emission at the beginning of incubation, which originates mainly from the amendment addition and represents a similar pathway for all treatments. However, for the pool 2 emission we could observe a significant difference when compared the two wet treatments (SAT/sat and HALFSAT/sat: $(-5.6 \pm 7.0))$ with the UNSAT/sat treatment $(+3.8 \pm 5.8)$. This represents the emission from unamended soil which was dominating after the third day of the incubation and indicates higher nitrification contribution for the drier treatment.

\subsection{Contribution of bacterial denitrification}

An endmember mixing approach has been previously used to estimate the fraction of bacterial $\mathrm{N}_{2} \mathrm{O}\left(\% B_{\mathrm{DEN}}\right)$, but without independent estimates of $\mathrm{N}_{2} \mathrm{O}$ reduction (Zou et al., 2014), but due to the unknown isotopic shift by $\mathrm{N}_{2} \mathrm{O}$ reduction, the ranges of minimum and maximum estimates were large, showing that limited information is obtained without $\mathrm{N}_{2}$ flux measurement.

In an incubation study with two arable soils, Koster et al. (2013) used $\mathrm{N}_{2} \mathrm{O} /\left(\mathrm{N}_{2}+\mathrm{N}_{2} \mathrm{O}\right)$ ratios and isotopocule values of gaseous fluxes to calculate $\mathrm{SP}$ of $\mathrm{N}_{2} \mathrm{O}$ production (referred to as $\mathrm{SP}_{0}$ ), which is equivalent to $\mathrm{SP}_{0}$ using the Rayleigh model and published values of $\eta_{\mathrm{N}_{2} \mathrm{O}-\mathrm{N}_{2}}$. The endmember mixing approach based on $\mathrm{SP}_{0}$ was then used to estimate fungal denitrification and/or hydroxylamine oxidation, giving indications for a substantial contribution in a clay soil, but not in a loamy soil. Here we presented for the first time an extensive dataset with large range in product ratios and moisture to calculate the contribution of bacterial denitrification $\left(\% B_{\mathrm{DEN}}\right)$ of emitted $\mathrm{N}_{2} \mathrm{O}$ from $\mathrm{SP}_{0}$. The uncertainty of this approach arises from three factors: (i) from the range of $\mathrm{SP}_{0}$ endmember values for bacterial denitrification of -11 to $0 \%$ o and 30 to 37 for hydroxylamine oxidation/fungal denitrification, (ii) from the range of net isotope effect values of $\mathrm{N}_{2} \mathrm{O}$ reduction $\left(\eta_{\mathrm{N}_{2} \mathrm{O}-\mathrm{N}_{2}}\right)$ for SP which vary from -2 to $-8 \%$ o
(Lewicka-Szczebak et al., 2015), and (iii) system condition (open vs. closed) taken to estimate the net isotope effect (Wu et al., 2016).

The observation that $\% B_{\text {DEN }}$ of emitted $\mathrm{N}_{2} \mathrm{O}$ was generally high $(63-100 \%)$ in the wettest treatment (SAT/sat) was not unexpected. However, interestingly, $\% B_{\mathrm{DEN}}$ in the HALFSAT/sat treatment was very similar (71-98\%), pointing to the role of the wetter areas of the soil microaggregates contributing to high $\% B_{\mathrm{DEN}}$ values. The slightly lower values, i.e. down $60 \%$ in UNSAT/sat $\% B_{\mathrm{DEN}}$ range of 60 $100 \%$, suggest that the majority of $\mathrm{N}_{2} \mathrm{O}$ derived from bacterial denitrification still results from the wetter microaggregates of the soils, despite the fact that the macropores are now more aerobic. Only when the micropores become partially wet, as in the UNSAT/halfsat treatment, do the more aerobic soil conditions allow a higher contribution of nitrification/fungal denitrification, ranging from 0 to $46 \%$ (1 $\% B_{\text {DEN }}$, Table 6) on days 3-12 (Zhu et al., 2013). Differences in the contribution of nitrification/fungal denitrification between the flux phases when different $\mathrm{NO}_{3}^{-}$pools were presumably dominating are only indicated in the driest treatment, since $1-\% B_{\mathrm{DEN}}$ was higher after day $2(14$ to $46 \%)$ compared to days $1+2(0$ to $33 \%)$. This larger share of nitrification/fungal denitrification can be attributed to the increasing contribution from pool 2 to the total flux as indicated by the modelling of higher $\mathrm{SP}_{0}$ for pool 2 (see previous section and Lewicka-Szczebak et al. (2015). In addition, indications for elevated contribution of processes other than bacterial denitrification were only evident in the drier treatments during phases before and after $\mathrm{N}_{2}$, and $\mathrm{N}_{2} \mathrm{O}$ fluxes were strongly enhanced by glucose amendment. The data supply no clue whether the other processes were suppressed during the anoxia induced by glucose decomposition or just masked by the vast glucose-induced bacterial $\mathrm{N}_{2} \mathrm{O}$ fluxes.

\section{Conclusions}

This study combined direct measurements of $\mathrm{N}_{2}$ as an indicator of denitrification with isotopomers, providing a measurement approach that verifies the source processes of $\mathrm{N}_{2} \mathrm{O}$ emissions. The results from this study demonstrated that at high soil moisture levels, there was less variability in $\mathrm{N}$ fluxes between replicates, potentially decreasing the importance of soil hot spots in emissions at these moisture levels. At high moisture there was also complete depletion of nitrate, confirming denitrification as the main pathway for $\mathrm{N}_{2} \mathrm{O}$ emissions, and due to less diffusion of the produced $\mathrm{N}_{2} \mathrm{O}$, the potential for further reduction to $\mathrm{N}_{2}$ increased. Under less saturation, but still relatively high soil moisture, nitrification occurred. Isotopic similarities were observed between similar saturation levels and patterns of $\delta^{15} \mathrm{~N} / \delta^{18} \mathrm{O}$ and $\mathrm{SP} / \delta^{18} \mathrm{O}$ are suggested as indicators of source processes. 
Data availability. Data are available on request from Laura Cardenas at laura.cardenas@ rothamsted.ac.uk.

\section{The Supplement related to this article is available online at https://doi.org/10.5194/bg-14-4691-2017-supplement.}

Competing interests. The authors declare that they have no conflict of interest.

Acknowledgements. The authors would like to thank Mark Butler for the technical help during the laboratory incubation and Andrew Bristow and Patricia Butler for carrying out soil analysis. Thanks also go to Dan Dhanoa for advice on statistical analysis, and to Anette Giesemann and Martina Heuer for help in $\mathrm{N}_{2} \mathrm{O}$ isotopic analyses. This study was funded by the UK Biotechnology and Biological Sciences Research Council (BBSRC) with competitive grants BB/E001580/1 and BB/E001793/1. Rothamsted Research is sponsored by the BBSRC.

Edited by: Yakov Kuzyakov

Reviewed by: Yushu Zhang and five anonymous referees

\section{References}

Avery, B. W.: Soil Classification for England and Wales (Higher Categories), Soil Survey of England and Wales, Soil Survey Technical Monograph No. 14, Harpenden, UK, 1980.

Baggs, E. M.: A review of stable isotope techniques for $\mathrm{N}_{2} \mathrm{O}$ source partitioning in soils: recent progress, remaining challenges and future considerations, Rapid Commun. Mass Sp., 22, 1664 1672,2008

Baggs, E. M., Rees, R. M., Smith, K. A., and Vinten, A. J. A.: Nitrous oxide emission from soils after incorporating crop residues, Soil Use Manage., 16, 82-87, 2000.

Ball, B. C., Scott, A., and Parker, J. P.: Field $\mathrm{N}_{2} \mathrm{O}, \mathrm{CO}_{2}$ and $\mathrm{CH}_{4}$ fluxes in relation to tillage, compaction and soil quality in Scotland, Soil Till. Res., 53, 29-39, 1999.

Barré, P., Eglin, T., Christensen, B. T., Ciais, P., Houot, S., Kätterer, T., van Oort, F., Peylin, P., Poulton, P. R., Romanenkov, V., and Chenu, C.: Quantifying and isolating stable soil organic carbon using long-term bare fallow experiments, Biogeosciences, 7 , 3839-3850, https://doi.org/10.5194/bg-7-3839-2010, 2010.

Bateman, E., Cadisch, G., and Baggs, E.: Soil water content as a factor that controls $\mathrm{N}_{2} \mathrm{O}$ production by denitrification and autotrophic and heterotrophic nitrification. Controlling nitrogen flows and losses, 12th Nitrogen Workshop, University of Exeter, UK, 21-24 September 2003, 290-292, 2004.

Bergstermann, A., Cardenas, L., Bol, R., Gilliam, L., Goulding, K., Meijide, A., Scholefield, D., Vallejo, A., and Well, R.: Effect of antecedent soil moisture conditions on emissions and isotopologue distribution of $\mathrm{N}_{2} \mathrm{O}$ during denitrification, Soil Biol. Biochem., 43, 240-250, 2011.
Bol, R., Rockmann, T., Blackwell, M., and Yamulki, S.: Influence of flooding on delta N-15, delta O-18, (1)delta N-15 and (2)delta N15 signatures of $\mathrm{N}_{2} \mathrm{O}$ released from estuarine soils - a laboratory experiment using tidal flooding chambers, Rapid Commun. Mass Sp., 18, 1561-1568, 2004.

Butterbach-Bahl, K., Baggs, E. M., Dannenmann, M., Kiese, R., and Zechmeister-Boltenstern, S.: Nitrous oxide emissions from soils: how well do we understand the processes and their controls?, Philos. T. R. Soc. B., 368, 20130122, https://doi.org/10.1098/rstb.2013.0122, 2013.

Cardenas, L. M., Hawkins, J. M. B., Chadwick, D., and Scholefield, D.: Biogenic gas emissions from soils measured using a new automated laboratory incubation system, Soil Biol. Biochem., 35, 867-870, 2003.

Castellano, M. J., Schmidt, J. P., Kaye, J. P., Walker, C., Graham, C. B., Lin, H., and Dell, C. J.: Hydrological and biogeochemical controls on the timing and magnitude of nitrous oxide flux across an agricultural landscape, Glob. Change Biol., 16, 2711-2720, 2010.

Clayden, B. and Hollis, J. M.: Criteria for differentiating soil series, Soil Survey Technical Monograph, No. 17, Harpenden, UK. 1984.

Clough, T. J., Müller, C., and Laughlin, R. J.: Using stable isotopes to follow excreta $\mathrm{N}$ dynamics and $\mathrm{N}_{2} \mathrm{O}$ emissions in animal production systems, Animal, 7, 418-426, 2013.

Cochran, W. G. and Cox, G. M.: Experimental Design, John Wiley \& Sons New York, 1957

Crutzen, P. J.: Influence of Nitrogen Oxides on Atmospheric Ozone Content, Q. J. Roy. Meteor. Soc., 96, 320-\&, 1970.

Davidson, E. A.: Fluxes of nitrous oxide and nitric oxide from terrestrial ecosystems, in: Microbial production and consumption of greenhouse gases: Methane, nitrogen oxides and halomethanes, edited by: Rogers, J. E. and Whitman, W. B., American Society for Microbiology, Washington, D.C., 219-235, 1991.

Davidson, E. A. and Verchot, L. V.: Testing the hole-in-the-pipe model of nitric and nitrous oxide emissions from soils using the TRAGNET database, Global Biogeochem. Cy., 14, 1035-1043, 2000.

Davidson, E. A., Hart, S. C., Shanks, C. A., and Firestone, M. K.: Measuring Gross Nitrogen Mineralization, Immobilization, and Nitrification by N-15 Isotopic Pool Dilution in Intact Soil Cores, J. Soil Sci., 42, 335-349, 1991.

Davidson, E. A., Keller, M., Erickson, H. E., Verchot, L. V., and Veldkamp, E.: Testing a conceptual model of soil emissions of nitrous and nitric oxides, Bioscience, 50, 667-680, 2000.

Decock, C. and Six, J.: On the potential of delta O-18 and delta N15 to assess $\mathrm{N}_{2} \mathrm{O}$ reduction to $\mathrm{N}_{2}$ in soil, Eur. J. Soil Sci., 64, 610-620, 2013.

del Prado, A., Merino, P., Estavillo, J. M., Pinto, M., and GonzalezMurua, C.: $\mathrm{N}_{2} \mathrm{O}$ and $\mathrm{NO}$ emissions from different $\mathrm{N}$ sources and under a range of soil water contents, Nutr. Cycl. Agroecosys., 74, 229-243, 2006.

Deppe, M., Well, R., Giesemann, A., Spott, O., and Flessa, H.: Soil $\mathrm{N}_{2} \mathrm{O}$ fluxes and related processes in laboratory incubations simulating ammonium fertilizer depots, Soil Biol. Biochem., 104, 68-80, 2017.

Dobbie, K. E. and Smith, K. A.: The effects of temperature, waterfilled pore space and land use on $\mathrm{N}_{2} \mathrm{O}$ emissions from an imperfectly drained gleysol, Eur. J. Soil Sci., 52, 667-673, 2001. 
Firestone, M. K. and Davidson, E. A.: Microbiological basis of NO and $\mathrm{N}_{2} \mathrm{O}$ production and consumption in soil, Life Sci. R., 47, 7-21, 1989.

Geisseler, D., Horwath, W. R., Joergensen, R. G., and Ludwig, B.: Pathways of nitrogen utilization by soil microorganisms - A review, Soil Biol. Biochem., 42, 2058-2067, 2010.

Gregory, A. S., Bird, N. R. A., Whalley, W. R., Matthews, G. P., and Young, I. M.: Deformation and Shrinkage Effects on the Soil Water Release Characteristic, Soil Sci. Soc. Am. J., 74, 11041112, 2010.

Harter, J., Guzman-Bustamente, I., Kuehfuss, S., Ruser, R., Well, R., Spott, O., Kappler, A., and Behrens, S.: Gas entrapment and microbial $\mathrm{N}_{2} \mathrm{O}$ reduction reduce $\mathrm{N}_{2} \mathrm{O}$ emissions from a biocharamended sandy clay loam soil, Scientific Reports, 6, 39574, https://doi.org/10.1038/srep39574, 2016.

Hatch, D. J., Sprosen, M. S., Jarvis, S. C., and Ledgard, S. F.: Use of labelled nitrogen to measure gross and net rates of mineralization and microbial activity in permanent pastures following fertilizer applications at different time intervals, Rapid Commun. Mass Sp., 16, 2172-2178, 2002.

IPCC: 2006 IPCC Guidelines for National Greenhouse Gas Inventories. 2006 IPCC Guidelines for National Greenhouse Gas Inventories, Prepared by the National Greenhouse Gas Inventories Programme, edited by: Eggleston, H. S., Buendia, L., Miwa, K., Ngara, T., and Tanabe, K., IGES, Japan, 2006.

Klefoth, R. R., Clough, T. J., Oenema, O., and Van Groenigen, J.W.: Soil Bulk Density and Moisture Content Influence Relative Gas Diffusivity and the Reduction of Nitrogen-15 Nitrous Oxide, Vadose Zone J., 13, https://doi.org/10.2136/vzj2014.07.0089, 2014.

Koster, J. R., Well, R., Dittert, K., Giesemann, A., LewickaSzczebak, D., Muhling, K. H., Herrmann, A., Lammel, J., and Senbayram, M.: Soil denitrification potential and its influence on $\mathrm{N}_{2} \mathrm{O}$ reduction and $\mathrm{N}_{2} \mathrm{O}$ isotopomer ratios, Rapid Commun. Mass Sp., 27, 2363-2373, 2013.

Koster, J. R., Cardenas, L. M., Bol, R., Lewicka-Szczebak, D., Senbayram, M., Well, R., Giesemann, A., and Dittert, K.: Anaerobic digestates lower $\mathrm{N}_{2} \mathrm{O}$ emissions compared to cattle slurry by affecting rate and product stoichiometry of denitrification An $\mathrm{N}_{2} \mathrm{O}$ isotopomer case study, Soil Biol. Biochem., 84, 65-74, 2015.

Kulkarni, M. V., Groffman, P. M., and Yavitt, J. B.: Solving the global nitrogen problem: it's a gas!, Front. Ecol. Environ., 6, 199-206, 2008.

Laudone, G. M., Matthews, G. P., Bird, N. R. A., Whalley, W. R., Cardenas, L. M., and Gregory, A. S.: A model to predict the effects of soil structure on denitrification and $\mathrm{N}_{2} \mathrm{O}$ emission, J. Hydrol., 409, 283-290, 2011.

Lewicka-Szczebak, D., Well, R., Koster, J. R., Fuss, R., Senbayram, M., Dittert, K., and Flessa, H.: Experimental determinations of isotopic fractionation factors associated with $\mathrm{N}_{2} \mathrm{O}$ production and reduction during denitrification in soils, Geochim. Cosmochim. Ac., 134, 55-73, 2014.

Lewicka-Szczebak, D., Well, R., Bol, R., Gregory, A.S., Matthews, G.P., Misselbrook, T., Whalley, W. R., and Cardenas, L. M.: Isotope fractionation factors controlling isotopocule signatures of soil-emitted $\mathrm{N}_{2} \mathrm{O}$ produced by denitrification processes of various rates, Rapid Commun. Mass Sp., 29, 269-282, 2015.
Lewicka-Szczebak, D., Augustin, J., Giesemann, A., and Well, R.: Quantifying $\mathrm{N}_{2} \mathrm{O}$ reduction to $\mathrm{N}_{2}$ based on $\mathrm{N}_{2} \mathrm{O}$ isotopocules - validation with independent methods (helium incubation and ${ }^{15} \mathrm{~N}$ gas flux method), Biogeosciences, 14, 711-732, https://doi.org/10.5194/bg-14-711-2017, 2017.

Liu, S. R., Herbst, M., Bol, R., Gottselig, N., Putz, T., Weymann, D., Wiekenkamp, I., Vereecken, H., and Bruggemann, N.: The contribution of hydroxylamine content to spatial variability of $\mathrm{N}_{2} \mathrm{O}$ formation in soil of a Norway spruce forest, Geochim. Cosmochim. Ac., 178, 76-86, 2016.

Loick, N., Dixon, L., Abalos, D., Vallejo, A., Matthews, G. P., McGeough, K. L., Well, R., Watson, C. J., Laughlin, R. J., and Cardenas, L. M.: Denitrification as a Source of Nitric Oxide Emissions from a UK Grassland Soil, Soil Biol. Biochem., 95, 1-7, 2016.

Ludwig, B., Bergstermann, A., Priesack, E., and Flessa, H.: Modelling of crop yields and $\mathrm{N}_{2} \mathrm{O}$ emissions from silty arable soils with differing tillage in two long-term experiments, Soil Till. Res., 112, 114-121, 2011.

Mariotti, A., Germon, J. C., and Leclerc, A.: Nitrogen isotope fractionation associated with the NO-2- $\mathrm{N}_{2} \mathrm{O}$ step of denitrification in soils, Can. J. Soil Sci., 62, 227-241, 1982.

Meijide, A., Cardenas, L.M., Bol, R., Bergstermann, A., Goulding, K., Well, R., Vallejo, A., and Scholefield, D.: Dual isotope and isotopomer measurements for the understanding of $\mathrm{N}_{2} \mathrm{O}$ production and consumption during denitrification in an arable soil, Eur. J. Soil Sci., 61, 364-374, 2010.

Morley, N. and Baggs, E. M.: Carbon and oxygen controls on $\mathrm{N}_{2} \mathrm{O}$ and $\mathrm{N}_{2}$ production during nitrate reduction, Soil Biol. Biochem., 42, 1864-1871, 2010.

Müller, C. and Clough, T. J.: Advances in understanding nitrogen flows and transformations: gaps and research pathways, J. Agric. Sci., 152, S34-S44, 2014.

Nadeem, S., Dorsch, P., and Bakken, L. R.: Autoxidation and acetylene-accelerated oxidation of NO in a 2-phase system: Implications for the expression of denitrification in ex situ experiments, Soil Biol. Biochem., 57, 606-614, 2013.

Ostrom, N. and Ostrom, P.: The isotopomers of nitrous oxide: analytical considerations and application to resolution of microbial production pathways, in: Handbook Environ Isot Geochem., edited by: Baskaran, M., Springer, Berlin Heidelberg, 453-476, 2011.

Parton, W. J., Holland, E. A., Del Grosso, S. J., Hartman, M. D., Martin, R. E., Mosier, A. R., Ojima, D. S., and Schimel, D. S.: Generalized model for NOx and $\mathrm{N}_{2} \mathrm{O}$ emissions from soils, J. Geophys. Res-Atmos., 106, 17403-17419, 2001.

Perez, T., Garcia-Montiel, D., Trumbore, S., Tyler, S., De Camargo, P., Moreira, M., Piccolo, M., and Cerri, C.: Nitrous oxide nitrification and denitrification $\mathrm{N}-15$ enrichment factors from Amazon forest soils, Ecol. Appl., 16, 2153-2167, 2006.

Scheer, C., Wassmann, R., Butterbach-Bahl, K., Lamers, J. P. A., and Martius, C.: The relationship between $\mathrm{N}_{2} \mathrm{O}$, NO, and $\mathrm{N}_{2}$ fluxes from fertilized and irrigated dryland soils of the Aral Sea Basin, Uzbekistan, Plant Soil, 314, 273-283, 2009.

Schmidt, U., Thoni, H., and Kaupenjohann, M.: Using a boundary line approach to analyze $\mathrm{N}_{2} \mathrm{O}$ flux data from agricultural soils, Nutr. Cycl. Agroecosys., 57, 119-129, 2000. 
Scholefield, D., Patto, P. M., and Hall, D. M.: Laboratory Research on the Compressibility of 4 Topsoils from Grassland, Soil Till. Res., 6, 1-16, 1985.

Searle, P. L.: The Berthelot or Indophenol Reaction and Its Use in the Analytical-Chemistry of Nitrogen - a Review, Analyst, 109, 549-568, 1984.

Sutka, R. L., Ostrom, N. E., Ostrom, P. H., Breznak, J. A., Gandhi, H., Pitt, A. J., and Li, F.: Distinguishing nitrous oxide production from nitrification and denitrification on the basis of isotopomer abundances, Appl. Environ. Microb., 72, 638-644, 2006.

Toyoda, S. and Yoshida, N.: Determination of nitrogen isotopomers of nitrous oxide on a modified isotope ratio mass spectrometer, Anal. Chem., 71, 4711-4718, 1999.

Toyoda, S., Mutobe, H., Yamagishi, H., Yoshida, N., and Tanji, Y.: Fractionation of $\mathrm{N}_{2} \mathrm{O}$ isotopomers during production by denitrifier, Soil Biol. Biochem., 37, 1535-1545, 2005.

van der Weerden, T. J., Kelliher, F. M., and de Klein, C. A. M.: Influence of pore size distribution and soil water content on nitrous oxide emissions, Soil Research, 50, 125-135, 2012.

van Groenigen, J. W., Kuikman, P. J., de Groot, W. J. M., and Velthof, G. L.: Nitrous oxide emission from urine-treated soil as influenced by urine composition and soil physical conditions, Soil Biol. Biochem., 37, 463-473, 2005.

Well, R. and Flessa, H.: Isotopologue signatures of $\mathrm{N}_{2} \mathrm{O}$ produced by denitrification in soils, J. Geophys. Res.-Biogeo., 114, G02020, https://doi.org/10.1029/2008JG000804, 2009.

Well, R., Augustin, J., Davis, J., Griffith, S. M., Meyer, K., and Myrold, D. D.: Production and transport of denitrification gases in shallow ground water, Nutr. Cycl. Agroecosys., 60, 65-75, 2001.
Well, R., Augustin, J., Meyer, K., and Myrold, D. D.: Comparison of field and laboratory measurement of denitrification and $\mathrm{N}_{2} \mathrm{O}$ production in the saturated zone of hydromorphic soils, Soil Biol. Biochem., 35, 783-799, 2003.

Well, R., Flessa, H., Xing, L., Ju, X. T., and Romheld, V.: Isotopologue ratios of $\mathrm{N}_{2} \mathrm{O}$ emitted from microcosms with $\mathrm{NH}_{4}^{+}$fertilized arable soils under conditions favoring nitrification, Soil Biol. Biochem., 40, 2416-2426, 2008.

Well, R., Eschenbach, W., Flessa, H., von der Heide, C., and Weymann, D.: Are dual isotope and isotopomer ratios of $\mathrm{N}_{2} \mathrm{O}$ useful indicators for $\mathrm{N}_{2} \mathrm{O}$ turnover during denitrification in nitratecontaminated aquifers?, Geochim. Cosmochim. Ac., 90, 265282, 2012.

Well, R., Kurganova, I., de Gerenyu, V. L., and Flessa, H.: Isotopomer signatures of soil-emitted $\mathrm{N}_{2} \mathrm{O}$ under different moisture conditions - A microcosm study with arable loess soil, Soil Biol. Biochem., 38, 2923-2933, 2006.

Wu, D., Koster, J. R., Cardenas, L. M., Bruggemann, N., LewickaSzczebak, D., and Bol, R.: $\mathrm{N}_{2} \mathrm{O}$ source partitioning in soils using $\mathrm{N}-15$ site preference values corrected for the $\mathrm{N}_{2} \mathrm{O}$ reduction effect, Rapid Commun. Mass Sp., 30, 620-626, 2016.

Zhu, X., Burger, M., Doane, T. A., and Horwath, W. R.: Ammonia oxidation pathways and nitrifier denitrification are significant sources of $\mathrm{N}_{2} \mathrm{O}$ and $\mathrm{NO}$ under low oxygen availability, P. Natl. Acad. Sci. USA., 110, 6328-6333, 2013.

Zou, Y., Hirono, Y., Yanai, Y., Hattori, S., Toyoda, S., and Yoshida, N.: Isotopomer analysis of nitrous oxide accumulated in soil cultivated with tea (Camellia sinensis) in Shizuoka, central Japan, Soil Biol. Biochem., 77, 276-291, 2014. 